Linköping University Medical Dissertations No. 1549

\title{
Mechanisms Behind Illness-Induced Anorexia
}

\author{
Anna Nilsson
}

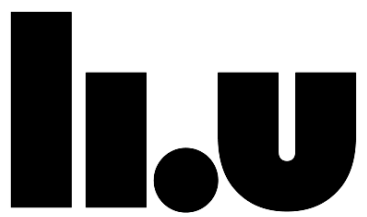

LINKÖPING UNIVERSITY

Department of Clinical and Experimental Medicine Linköping University, Sweden Linköping 2016 
(c)Anna Nilsson, 2016

Cover illustration A PhD-student's circle of life was designed and created by Sofie Sundberg.

Published articles have been reprinted with the permission of the copyright holders.

Printed in Sweden by LiU-Tryck, Linköping, Sweden, 2016

ISBN: 978-91-7685-648-2

ISSN: 0345-0082 


\section{Till Nils och Erik}

Den vinner som är trägen Den förlorar som ger upp

Lars Winnerbäck 


\section{ABSTRACT}

Loss of appetite is together with fever and malaise hallmarks of infection. Loosing appetite during an acute infection such as influenza does not result in any long-lasting effects, but loosing appetite during chronic diseases such as cancer or AIDS constitutes a risk factor for mortality. Food intake regulation during inflammation is orchestrated by the brain in response to peripheral inflammatory signals. It is known that expression of the prostaglandin synthesizing enzyme cyclooxygenase 2 (COX-2) is crucial for the mechanisms underlying inflammation-induced anorexia, and that prostaglandin E2 (PGE2) is involved in anorexia induced by interleukin-1 beta (IL-1 $\beta$ ). In this thesis I examined the prostaglandin pathways proposed to be involved in anorexia. We show that acute anorexia is dependent on COX-2 expression, while cancer-induced anorexia is mediated by cyclooxygenase 1 (COX-1), at least in the initial stages, suggesting that the signaling pathways for chronic- and acute anorexia are distinct. We were able to demonstrate that the pathway underlying acute anorexia is distinct from that of fever, and that taste aversion is prostaglandin independent. We could also show that both acute and chronic anorexia-cachexia is dependent on expression of myeloid differentiation primary response gene (MyD88) in hematopoietic/myeloid cells.

In summary, the findings presented in this thesis suggest that anorexia is a result of many different signaling pathways, as opposed to what is the case for several other inflammatory symptoms such as fever and malaise, where the pathways have been shown to be very exclusive. This provides new insight into the diversity of the pathways underlying inflammatory symptoms, which is fundamental for the ability to present potential, symptom-specific drug targets. 


\section{POPULÄRVETENSKAPLIG}

\section{SAMMANFATTNING}

Det har varit mycket att göra en period på jobbet. Du känner dig trött, men just idag känns det lite annorlunda. Trots tre koppar kaffe vill kroppen och huvudet inte riktigt komma igång. Strax före lunch börjar du tycka att det drar kallt från fönstret på kontoret. Du är inte speciellt hungrig, och du tycker att ljudet från din kontorskollegas tangentbord ekar i öronen. Huvudvärken tilltar och du inser att det inte är någon mening att kämpa emot längre. Du packar ihop dina saker, åker hem, tar en Alvedon och går och lägger dig.

Vad som hänt är att du drabbats av en infektion av något slag. Våra kroppar utsätts hela tiden för angrepp från olika mikrober och ibland tar de sig förbi våra försvarsbarriärer och gör oss sjuka. De vanligaste symptomen vi får då är feber, trötthet, aptitförlust och att vi drar oss tillbaka och inte vill vistas med någon. Dessa symptom orsakas av att mikroberna har molekyler som känns igen av celler i vårt immunförsvar. Dessa celler kommer då att skicka ut molekyler, så kallade cytokiner och kemokiner, som kan aktivera ytterligare delar av immunförsvaret, så att en effektiv bekämpning av mikroberna kan ske.

Dessa molekyler påverkar inte bara immunförsvaret utan även hjärnan. Alla symptom som man upplever när man är sjuk förmedlas av hjärnan. I denna avhandling har jag studerat mekanismerna som ligger bakom att vi tappar aptiten när vi blir sjuka. Detta har jag studerat genom att undersöka ett specifikt signalsystem, nämligen bildningen av prostaglandiner. Prostaglandiner har många funktioner i kroppen även under normala förhållanden (så kallad homeostas) och syntesen av prostaglandinerna styrs av två olika klasser av enzymer: cyklooxygenaserna (COX-1 och COX-2) och de prostaglandinsyntetiserande terminala enzymerna. Några av dessa sköter produktionen av prostaglandiner under normala förhållanden och påverkas inte av inflammation, 
medan andra är inflammationsdrivna. Det är de som påverkas av inflammation som vi har undersökt betydelsen av vid aptitförlust.

Vi har även undersökt om detta system är inblandat vid utvecklingen av ett symptom som kallas för kakexi som man ofta ser hos patienter med kroniska sjukdomar. Förutom aptitförlust drabbas dessa patienter även av förändrad metabolism. Viktnedgången som kakexi-patienter har beror till stor del på förlust av muskler till skillnad från vid vanlig svält, då det främst är fettdepåerna som minskar.

Resultatet från denna avhandling visar att den aptitförlust som orsakas av akuta tillstånd, såsom influensa, till stor del beror av aktivering av enzymet COX-2, vilket redan var känt sedan innan. Vårt mål var att kunna visa i vilken celltyp som COX-2 aktiveras i, men i nuläget kan vi bara visa på vilka celltyper det inte är. Vi har testat att hämma aktiveringen av COX-2 i nervceller, i celler i kärlväggen av blod-hjärnbarriären samt i celler från immunförsvaret (myeloida celler), men ingen av celltyperna visade sig vara enskilt inblandad. Vi testade även att hämma en signalmolekyl som har betydelse vid igenkänningen av mikrober (MyD88) med samma tillvägagångssätt och fann då att aktivering av denna signalmolekyl i immunförsvarets celler är av betydelse för utvecklingen av aptitförlust. MyD88 aktivering i dessa celler var även i hög grad inblandad i utvecklingen av aptitförlust och viktnedgång vid cancersjukdom. Vi kunde även visa att COX-1, som annars betraktas som ett av enzymen som inte påverkas av inflammation, är av betydelse för igångsättningen av aptitförlusten hos tumörbärande möss. Ett annat viktigt fynd är att den inflammatoriska signaleringen bakom aptitförlust och feber har olika sätt att ta sig in i hjärnan och att dessa två symptom inte är lika sammanflätade som man tidigare trott.

De generella slutsatser vi kan dra av studierna som ligger till grund för denna avhandling är att symptomen som vi upplever när vi blir sjuka, och som länge har ansetts ha samma bakomliggande signalvägar, till stor del signaleras till hjärnan på olika sätt. Aptitförlusten som uppkommer vid en infektion är inte alls lika beroende av ett specifikt prostaglandin, prostaglandin E2, som man tidigare trott, men en viktig faktor för att utveckla aptitförlust både vid akut- och kronisk sjukdom verkar vara MyD88-signallering i kroppens immunceller. 
Att kartlägga hur dessa signalvägar fungerar och vad som skiljer olika sjukdomssymptom åt är av stor vikt för utvecklingen av nya läkemedel. Dagens receptfria anti-inflammatoriska läkemedel är visserligen effektiva, men påverkar många av kroppens homeostatiska processer. Det är därför vanligt med allvarliga biverkningar såsom nedsatt hjärtfunktion och ökad risk för stroke och hjärtinfarkt, påverkan på njurfunktionen och magsår vid kronisk användning av dessa preparat. Önskvärt vore om det fanns läkemedel som endast påverkade de processer som missgynnar välmående. 


\section{TABLE OF CONTENTS}

POPULÄRVETENSKAPLIG SAMMANFATTNING

Central regulation of food intake .................................................................................. 19

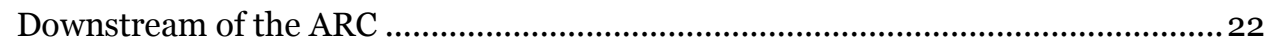

Initiation of the acute phase response ……………………........................................ 23

Taking an inflammatory signal from the periphery to the brain...................................24

Direct cytokine action ............................................................................................. 24

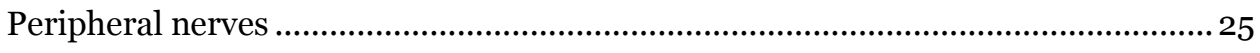

The blood brain barrier............................................................................................. 26

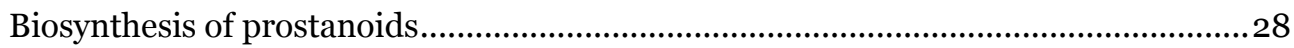

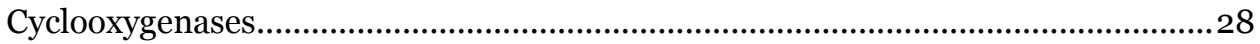

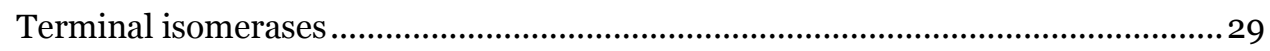

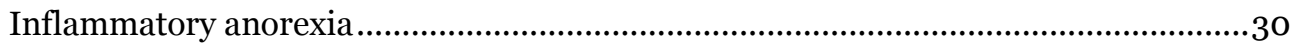

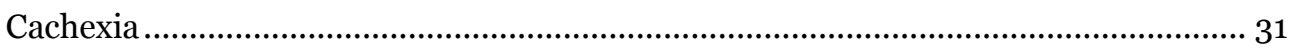


Centrally activated pathways mediating anorexia during systemic inflammation ......34

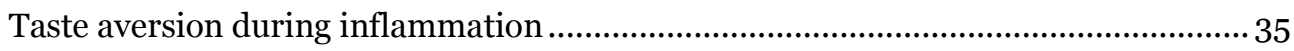

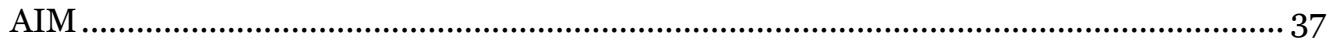

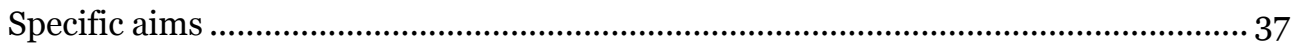

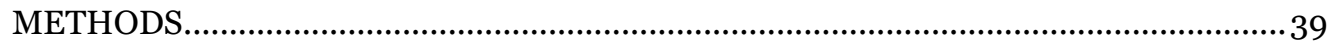

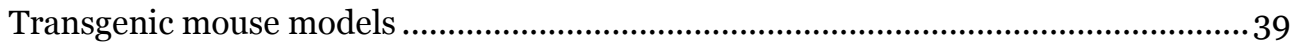

Acute inflammation models ......................................................................... 41

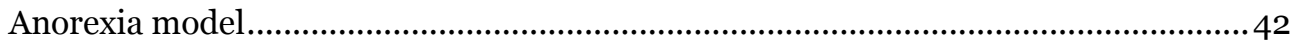

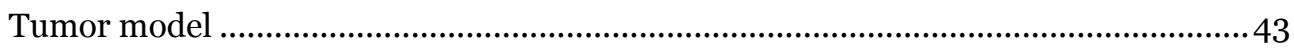

Body temperature recordings ......................................................................... 43

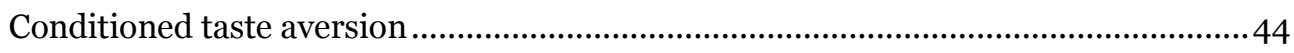

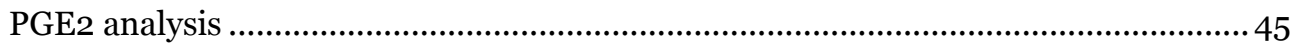

Gene and protein expression ........................................................................... 46

COX-inhibitors and PGE2 neutralization ........................................................ 47

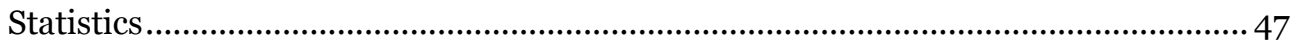

SUMMARY OF THE PAPERS .......................................................................... 49

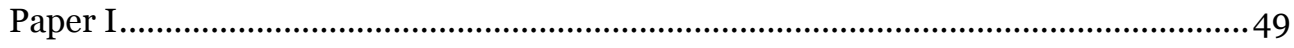

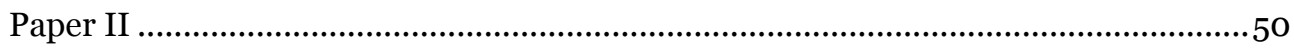

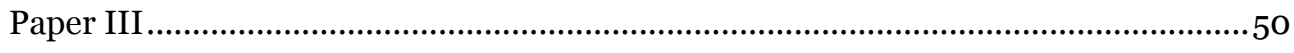

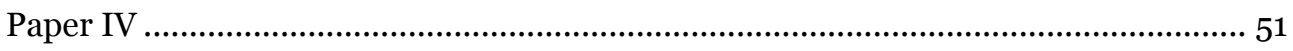

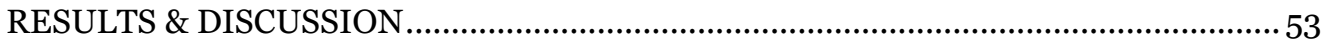

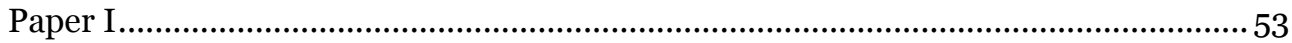

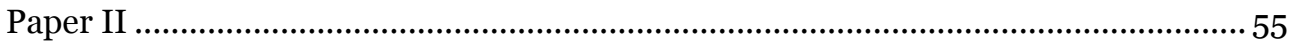

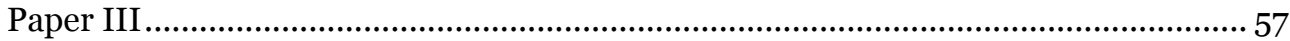




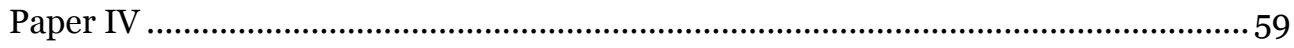

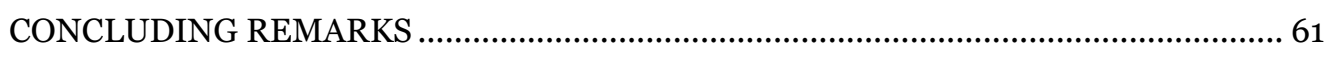

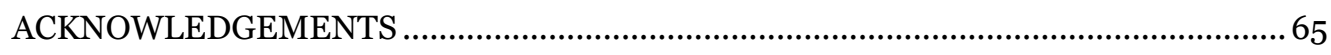

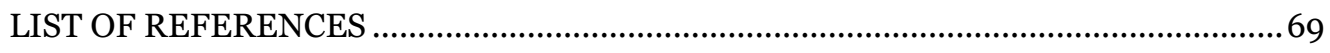




\section{LIST OF PAPERS}

I. Ruud J., Nilsson A., Engström L., Wenhua W., Nilsberth C., Iresjö B-M., Lundholm K., Engblom D., Blomqvist A. (2013) Cancer-induced anorexia in tumor-bearing mice is dependent on cyclooxygenase-1. Brain Behav Immun 29: 124-135.

II. Ruud J., Wilhelms DB., Nilsson A., Eskilsson A., Tang Y., Ströhle P., Caesar R., Schwanninger M., Wunderlich T., Bäckhed F., Engblom D., Blomqvist A. (2013) Inflammation- and tumor-induced anorexia and weight loss require MyD88 in hematopoietic/myeloid cells but not brain endothelial or neural cells. FASEB J. 27, 1973-1980.

III. Nilsson A., Elander L., Hallbeck M., Örtegren Kugelberg U., Engblom D., Blomqvist A. (2016) The involvement of prostaglandin E2 in interleukin-1 $\beta$ evoked anorexia is strain dependent. Brain Behav Immun Jun 29. PMID: 27375005.

IV. Nilsson A., Wilhelms DB, Mirrasekhian E., Jaarola M., Blomqvist A., Engblom D. (2016) Inflammation-induced anorexia and fever are elicited by distinct prostaglandin dependent mechanisms, whereas conditioned taste aversion is prostaglandin independent. Brain Behav Immun. Manuscript in revision. 


\section{ABBREVIATIONS}

$\begin{array}{ll}\text { AgRP } & \text { agouti-related peptide } \\ \text { a-MSH } & \text { alpha-melanocyte-stimulating hormone } \\ \text { ARC } & \text { arcuate nucleus } \\ \text { CART } & \text { cocaine- and amphetamine-regulated transcript } \\ \text { CCK } & \text { cholecystokinin } \\ \text { CGRP } & \text { calcitonin gene-related peptide } \\ \text { COX } & \text { cyclooxygenase } \\ \text { cPGES } & \text { cytosolic prostaglandin E synthase } \\ \text { CSF } & \text { cerebrospinal fluid } \\ \text { CTA } & \text { conditioned taste aversion } \\ \text { CVO } & \text { circumventricular organ } \\ \text { DNA } & \text { deoxyribonucleic acid } \\ \text { EP } & \text { prostaglandin E2 receptor } \\ \text { GI } & \text { gastrointestinal } \\ \text { GLP-1 } & \text { glucagon-like peptide-1 } \\ \text { IFN- } \gamma & \text { interferon gamma } \\ \text { IL } & \text { interleukin } \\ \text { i.p. } & \text { intraperitoneal } \\ \text { KO } & \text { knock-out } \\ \text { LBP } & \text { lateral hypothalamus } \\ \text { LHA } & \end{array}$




$\begin{array}{ll}\text { LiCl } & \text { lithium chloride } \\ \text { LPS } & \text { lipopolysaccharide } \\ \text { MC3-R } & \text { melanocortin-3 receptor } \\ \text { MC4-R } & \text { melanocortin-4 receptor } \\ \text { mPGES } & \text { microsomal prostaglandin E synthase } \\ \text { mRNA } & \text { messenger ribonucleic acid } \\ \text { MyD88 } & \text { myeloid differentiation primary response gene 88 } \\ \text { NFkB } & \text { nuclear factor kappa B } \\ \text { NPY } & \text { neuropeptide Y } \\ \text { NTS } & \text { nucleus of the solitary tract } \\ \text { PAMPs } & \text { pathogen-associated molecular patterns } \\ \text { PB } & \text { parabrachial nucleus } \\ \text { PCR } & \text { polymerase chain reaction } \\ \text { PGE2 } & \text { Prostaglandin E2 } \\ \text { p.o. } & \text { per os } \\ \text { POMC } & \text { pro-opiomelanocortin } \\ \text { PVH } & \text { paraventricular hypothalamus } \\ \text { PYY } & \text { peptide YY } \\ \text { qPCR } & \text { toll-like receptor } 4 \\ \text { RT-PCR } & \text { wild type } \\ \text { TLR4 } & \\ \text { TNF- } \alpha & \text { WT }\end{array}$





\section{INTRODUCTION}

\section{Food intake regulation}

All living things must consume nutrients to survive. The regulation of food intake in an organism is managed by an intricate network, with signals arising in the gastrointestinal (GI) tract and the oral cavity reaching primary target structures in the brain that in turn coordinate these signals to regulate a behavior of feeding or not feeding. It should be emphasized that the mechanisms described in the following sections are those regulatory mechanisms arising from food content, taste and amount. Hunger sensation is a subjective feeling and includes other factors, such as environmental, cultural and genetic, but the involvement of these and other conditioned behaviors is beyond the range of this thesis.

\section{Gastric regulation of food intake}

The gastrointestinal tract regulates food intake in two principle ways. The first is predominantly used by the stomach and includes mechanoreceptors that are activated by the stretching of the ventricle when it is filled with food during a meal. This will activate vagal and spinal afferents [1] terminating primarily in the nucleus of the solitary tract (NTS) in medulla oblongata which also receives input from the glossopharyngeal nerve that mediates taste sensations from the oral cavity. The NTS is an important center for feeding regulation that will be further described in the following chapters. The second major way that the GI tract uses for food intake regulation is hormonal. The content of the chyme is registered by the enteroendocrine cells in the intestinal mucosa of the small intestine, and these cells secrete peptide hormones in response to the content. 


\section{INTRODUCTION}

\section{Negative regulation of food intake}

One of the first hormones to be described as a food intake regulator was cholecystokinin (CCK) [2], which is released in response to lipid- and protein content in the duodenum and jejunum, and signals satiety by binding to receptors on vagal sensory terminals [3] signaling to NTS, or directly by binding primarily to receptors in the hypothalamus and the hindbrain (Figure 1). Another important factor for terminating a meal is glucagonlike peptide-1 (GLP-1) [4] which is secreted by the lower small intestine in response to glucose levels in the circulation and fat and carbohydrate content of the ingested food [5]. GLP-1 uses both peripheral and central pathways for inhibiting food intake. Peripherally, GLP-1 inhibits mobility of the small intestine as well as release of insulin from the pancreas [6], by binding to receptors in these effector sites. It has also been suggested that peripherally produced GLP-1 has direct anorectic properties via vagal afferents [5] (Figure 1) but the mechanism behind this has not yet been fully elucidated. Centrally, GLP-1 is expressed by a distinct population of neurons in the NTS that project to the hypothalamus [7] constituting a central pathway for GLP-1 to induce anorexia. The enteroendocrine cells expressing GLP-1 also express peptide YY (PYY), which cleavage product PYY $3-36$ is the active compound. Centrally, PYY3-36 inhibits feeding by binding to inhibitory Y2 receptors on orexigenic (feeding promoting) neurons [5] (Figure 2) leading to decrease in food intake. The levels of PYY decline just before meal initiation [8].

One hormone that has been the topic of an enormous number of studies during the last two decades is leptin. Leptin is the product of the $o b$ gene and is secreted by the adipocytes proportional to the amount of fat tissue in the organism [9, 10]. It binds to receptors (encoded by the $d b$ gene) in the hypothalamus [11-13] and the levels of leptin in the brain are proportional to the plasma levels [14]. Signaling through the leptin receptor results in a strong suppression of food intake, which is induced by activating anorexigenic neurons and inhibiting orexigenic neurons (Figure 2). The detailed mechanisms behind this regulatory function and the implications of this function will be explained in more detail in the next chapter. The finding and characterization of leptin and its receptor have revolutionized the field of metabolic research. Food intake regulation, which was previously considered to be a matter of discipline and self-control 
was now shown to be controlled by physiological processes, and fat tissue was shown to be able to act as an endocrine organ, opening up the possibility that adipocytes can engage in homeostatic regulation and take on other functions as well, such as being mediators of inflammation during some disease states.

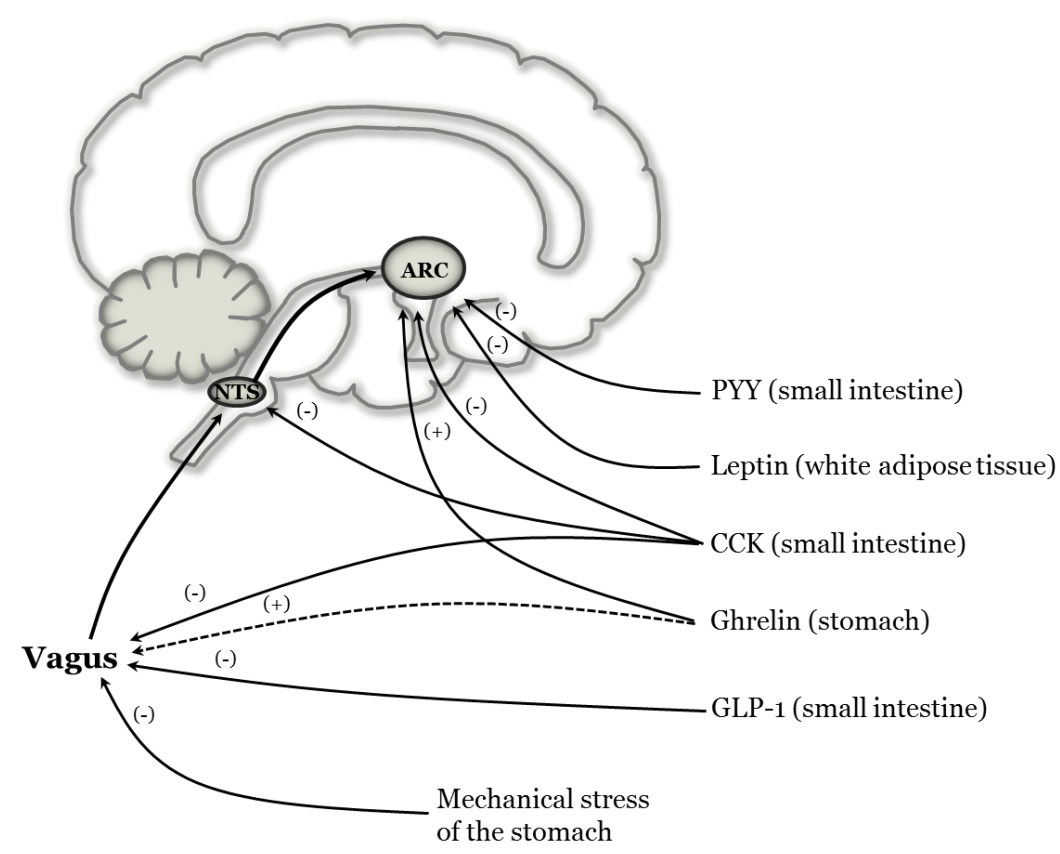

Figure 1. Feeding-regulating hormones are released by enteroendocrine cells in the GItract or white adipose tissue in response to the nutrient state, and influence food intakeregulation centers in the brain by direct or vagal mechanisms.

$(-)=$ anorexigenic signal, $(+)=$ orexigenic signal. For more details, see chapter about Food intake regulation. 


\section{INTRODUCTION}

\section{Positive regulation of food intake}

Ghrelin is commonly known as the hunger hormone and is expressed by the stomach and small intestine. The level of ghrelin is high just before a meal [15] and low just after [16]. The peripheral role of ghrelin is debated and the main focus of research within the ghrelin-field has been on its central roles. Ghrelin primarily acts by binding to ghrelinreceptors expressed by hypothalamic neurons that stimulate feeding [17] (Figure 1). It has been suggested that ghrelin can be produced locally in the hypothalamus by ghrelinexpressing neurons but this is still controversial [17]. 


\section{Central regulation of food intake}

The arcuate nucleus in the hypothalamus (ARC) and the NTS in the brain stem are the two single most important structures for feeding regulation. The hypothalamus primarily receives information from hormones in the circulatory system, whereas the brain stem mainly receives oral- and gastrointestinal information from cranial nerves in response to the amount and quality of the ingested food. Generally, the hypothalamus is in charge of meal initiation and the brain stem is in charge of meal termination [17]. However, it has been shown that signaling molecules classically belonging to the hypothalamic pathway can regulate food intake by brain stem mechanisms as well [1820], emphasizing the fine-tuned interplay behind the central mechanisms regulating food intake.

Within the ARC, there are two neuron populations that are the key regulators of food intake. One population consists of neurons expressing neuropeptide $Y$ (NPY) and agouti-related peptide (AgRP) and is responsible for stimulating appetite (orexigenic). The second population consists of neurons expressing pro-opiomelanocortin (POMC) and cocaine- and amphetamine- regulated transcript (CART) and mediates inhibition of food intake (anorexigenic). These two populations influence one another, and one is always more active than the other. Usually the POMC/CART is active (otherwise we would be eating all the time), but in response to feeding-promoting hormones or decreased levels of anorexigenic hormones the NPY/AgRP-expression cells will be activated [14]. This in turn will lead to inactivation of POMC/CART neurons, which persists until the levels of anorexigenic hormones increase as a result of the ingested food (Figure 2). 


\section{INTRODUCTION}

NPY is a very potent feeding stimulator [21] and its orexigenic effect is transduced through postsynaptic $\mathrm{Y}_{1}$ and $\mathrm{Y}_{5}$ receptors [14], which mainly function by inhibiting POMC/CART- and other downstream anorexigenic-signaling neurons. Ninety percent of the NPY neurons co-express AgRP [22, 23], which is why the neurons are often referred to as NPY/AgRP neurons. AgRP is a competitive antagonist of melanocortin 3- and 4 receptors $\left(\mathrm{MC}_{3}-\mathrm{R}, \mathrm{MC} 4-\mathrm{R}\right)$ [22], which are the main receptors by which POMC/CARTneurons exert their anorexigenic effect [20, 24, 25].

POMC is a precursor protein that is cleaved into multiple peptide hormones of which alpha-melanocyte-stimulating hormone ( $\alpha-\mathrm{MSH})$ is the most relevant for feeding regulation. Alpha-MSH binds to $\mathrm{MC}_{3}-\mathrm{R}$ and $\mathrm{MC}_{4}-\mathrm{R}$ which are expressed by both $\mathrm{NPY}$ /AgRP-neurons as well as second order neurons in target regions such as the lateral hypothalamus (LHA) and the paraventricular hypothalamus (PVH) [26]. Activation of $\mathrm{MC}_{3}-\mathrm{R}$ and $\mathrm{MC} 4-\mathrm{R}$ strongly induce suppression of appetite [24, 25, 27]. Co-expressed with POMC is CART [28, 29], which has been shown to mediate central release of GLP-1 [30], thereby potentiating the anorexic signal.

Both NPY/AgRP- and POMC/CART-neurons express receptors for important feedingregulatory peptides such as leptin and insulin [31,32] but the activation of these receptors have opposing effects: NPY/AgRP neurons are inhibited while POMC/CART neurons are activated, creating a strong and effective synergistic effect of the feedingregulatory signal (Figure 2). Interaction in the ARC also allows NPY/AgRP- and POMC/CART-neurons to influence one another, mostly by way of MC3-R, MC4-R and Y-receptors. 


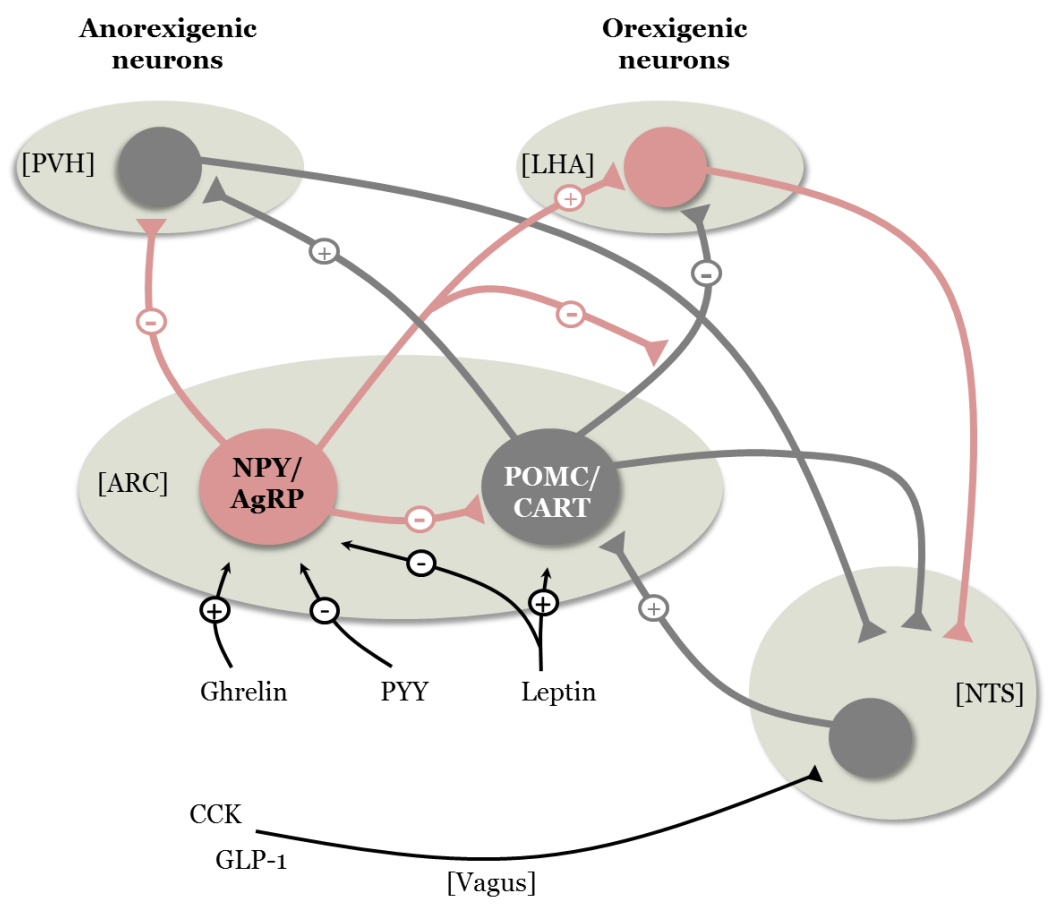

Figure 2. Basic principles of the effect of peripherally released feeding-hormones on NTS and cells within the ARC in the hypothalamus. Fibers from cells in the ARC innervate either the antagonizing neuron or second order neurons in PVH and LHA. The ability of the network to both inhibit and activate at the same time creates a strong potentiation of the effect of the feeding-regulatory hormones. Modified from Gompert B., Kramer I., Tatham P. Signal transduction, 2nd Edition. Academic Press 2009. 


\section{INTRODUCTION}

\section{Downstream of the ARC}

POMC- and NPY-neurons project in parallel paths to several downstream targets that are widely distributed throughout the brain (see more detailed review [17]). The targets of these projections that are particularly interesting regarding food intake regulation are the LHA, the PVH (Figure 2) and the parabrachial nucleus in the brainstem (PB). PVH is one of the most important autonomic control centers with essential roles in neuroendocrine and autonomic regulation, and it is thus involved in the conservation or expenditure of energy. Generally, $\mathrm{PVH}$ is a satiety center, favoring the inhibitory signals from POMC/CART and leptin, while LHA is proposed to be more involved in promoting feeding (Figure 2). However, both targets include receptors and projections involved in both hunger and satiety signaling and both receive innervation from the ARC as well as NTS [33]. The PB is innervated by the ARC as well as by NTS, making this an important auto regulatory nucleus for energy balance. 


\section{Initiation of the acute phase response}

Our bodies are continuously exposed to agents that can be potentially harmful. We have excellent systems that prevent these agents from infecting us, but sometimes these prove to be insufficient and we get ill. The symptoms of illness include fever, fatigue, food avoidance, mild depression and social withdrawal, which together provide a beneficial physiological state for the immune system to combat the infection. These symptoms also act as signals to both the ill individual and to others to avoid contact in order to prevent spread of the disease.

Upon infection, cells from the innate immune system at the site of infection, including macrophages and neutrophils, will produce inflammatory mediators in response to pathogen-associated molecular patterns (PAMPs) expressed by the microbes. One such PAMP is lipopolysaccharide (LPS), which is a component of the cell wall of gramnegative bacteria. LPS is of specific interest, since it is one of the most commonly used molecules for studying the acute-phase response in mice. LPS binds to LPS binding protein (LBP) [34]. The LPS-LBP complex is recognized by the Toll-like receptor-4 (TLR4), which belongs to the network of pattern-recognition receptors (PRRs). TLR4 is present on a large number of cell types, including dendritic cells, macrophages, mast cells and endothelial cells. Binding of LPS-LBP to TLR4 recruits the intracellular adapter protein myeloid differentiation primary response gene 88 (MyD88) which activates NF- $\mathrm{kB}$ [35]. This activation induces expression of cytokines, such as tumor necrosis factor alpha (TNF- $\alpha$ ), interleukin-1 beta (IL-1 $\beta$ ) and interleukin-6 (IL-6), and chemokines as well as enzymes such as cyclooxygenase (COX) and microsomal prostaglandin E synthase-1 (mPGES-1) to massively induce a pro-inflammatory immune response. The pro-inflammatory mediators will enter the circulatory system and affect specific targets in the brain, which are responsible for mediating sickness symptoms. 


\section{INTRODUCTION}

\section{Taking an inflammatory signal from the periphery to the brain}

The brain has long been considered as an immune-privileged organ, since it is protected from many molecules in the blood by the blood-brain barrier. This barrier consists of endothelial cells connected by tight junctions and their basal lamina, and, on the abluminal side, by processes from astrocytes, and perivascular macrophages. The barrier prevents infectious agents and many macromolecules in the blood from entering the brain parenchyma and the cerebrospinal fluid (CSF), and thus prevents them from causing damage to the brain. The blood-brain barrier is impermeable to diffusion of larger molecules such as cytokines, but it is nevertheless central responses that give rise to many of the symptoms seen during an infection (fever, anorexia, fatigue). Hence proinflammatory signals mediate effects in the brain and consequently there must be mechanisms by which inflammatory signals can be transmitted over the blood-brain barrier. The way by which this transduction has been suggested to occur involves three distinct signaling routes (Figure 3).

\section{Direct cytokine action}

Cytokines may act directly on neuronal receptors and active transporters for the most common cytokines have been described to be expressed by the blood-brain barrier [3639]. However, it is unlikely that these are of major importance for the symptoms during acute infection, since their involvement seems to appear quite slowly [40], and may thus be more relevant during chronic disease states.

In addition, there are areas in the brain that lack a blood-brain barrier; these areas are called the circumventricular organs (CVOs). They lie in close proximity to brain areas known to be involved in the response to immune challenge. The role of CVOs during immune challenge is, however, a matter of dispute [41-44]. The CVOs do not entirely lack a barrier, since it has been shown that tanycytes in these structures constitute a barrier, preventing large molecules such as cytokines from entering the brain parenchyma [45]. This does not, however, indicate that the CVOs are un-important during systemic inflammation. Cells in the CVOs have been shown to express both PAMPs [46-49], as well as pro-inflammatory cytokines during systemic inflammation 
[50, 51]. Projections from the CVOs innervate the hypothalamus [52, 53], hippocampus [54] and amygdala [52], and have been shown to be active during inflammation, indicating that the CVOs may constitute an important relay station for inflammatory signals to the brain.

\section{Peripheral nerves}

Perhaps the most obvious mechanism for transducing a signal from the periphery to the brain would be through peripheral nerves. In the setting of systemic inflammation, the most extensively studied candidate is the vagus nerve. Vagal afferents have been shown to express both PAMPs [55] and cytokine receptors [56, 57], suggesting that the vagus nerve is involved in mediating inflammatory signals from the periphery to the brain. As described in previous sections, the vagus nerve projects to NTS, which in turn innervates several brain regions, including the hypothalamus, which is a key structure for brain-mediated illness-responses. The role of vagal afferents is however debatable. It has been shown that LPS administration induces activation in NTS and the PVH [58], and that this effect is abolished in vagotomized rats [59], supporting the idea of the vagus as a mediator for inflammatory signals. However, behavioral readouts have generated contradictory results. Some studies indicate that subdiaphragmatic vagotomy blocks LPS- and IL-1 $\beta$-induced sickness responses [60, 61], while other studies show that subdiaphragmatic vagal deafferentation does not prevent anorexia after peripheral administration of LPS or IL-1 $\beta$ [62] and that prostaglandin E2 (PGE2) even is elevated in cerebrospinal fluid after bilateral vagotomy [63]. Contradictory results like these are not uncommon in this field. Subdiaphragmatic vagotomy is not entirely trivial, since it often results in a wide range of side effects, including malnutrition and abolished motility in the GI-tract, which can explain the diversity of behavioral outcomes in rodents after vagal deafferentation. 


\section{INTRODUCTION}

\section{The blood brain barrier}

Today, the most widely accepted and well established pathway of immune-to-brain signaling is present within the endothelial cells of the blood-brain barrier. These cells express IL-1 $\beta$-receptors and activation of these leads to activation of NF- $\kappa \mathrm{B}[49,64-67]$. Peripheral administration of LPS or IL-1 $\beta$ leads to expression of cyclooxygenase 2 (COX-2) [63, 68] and mPGES-1 [69] in the brain vasculature, and to the release of prostaglandin E2 (PGE2) into the brain parenchyma [70]. The cell type making the PGE2 is controversial, since some groups have shown the endothelial cells to be crucial [48, 67, 71-75], while others favor the perivascular macrophages [76, 77]. In 2011, Ridder et al. provided strong evidence for the involvement of the endothelial cells. They specifically deleted TAK-1, a MAP kinase that activates NF- $\kappa B$ and thereby promotes transcription of pro-inflammatory genes, in the endothelial cells of the blood-brain barrier, and could thereby prevent mice from developing both fever and lethargy [78]. The critical role of the endothelial cells is further supported by the finding that mice lacking the membrane-bound receptor for IL-6 on brain endothelial cells show attenuated fever after LPS administration as well as a strong reduction of COX-2 expression in the brain [79]. Recently it was also shown that deleting COX-2 or mPGES1 specifically in brain endothelial cells strongly attenuates the fever response after LPS injection [8o]. Together these findings show that endothelial cells are important for translating the peripheral inflammatory signal into centrally induced illness-responses. 


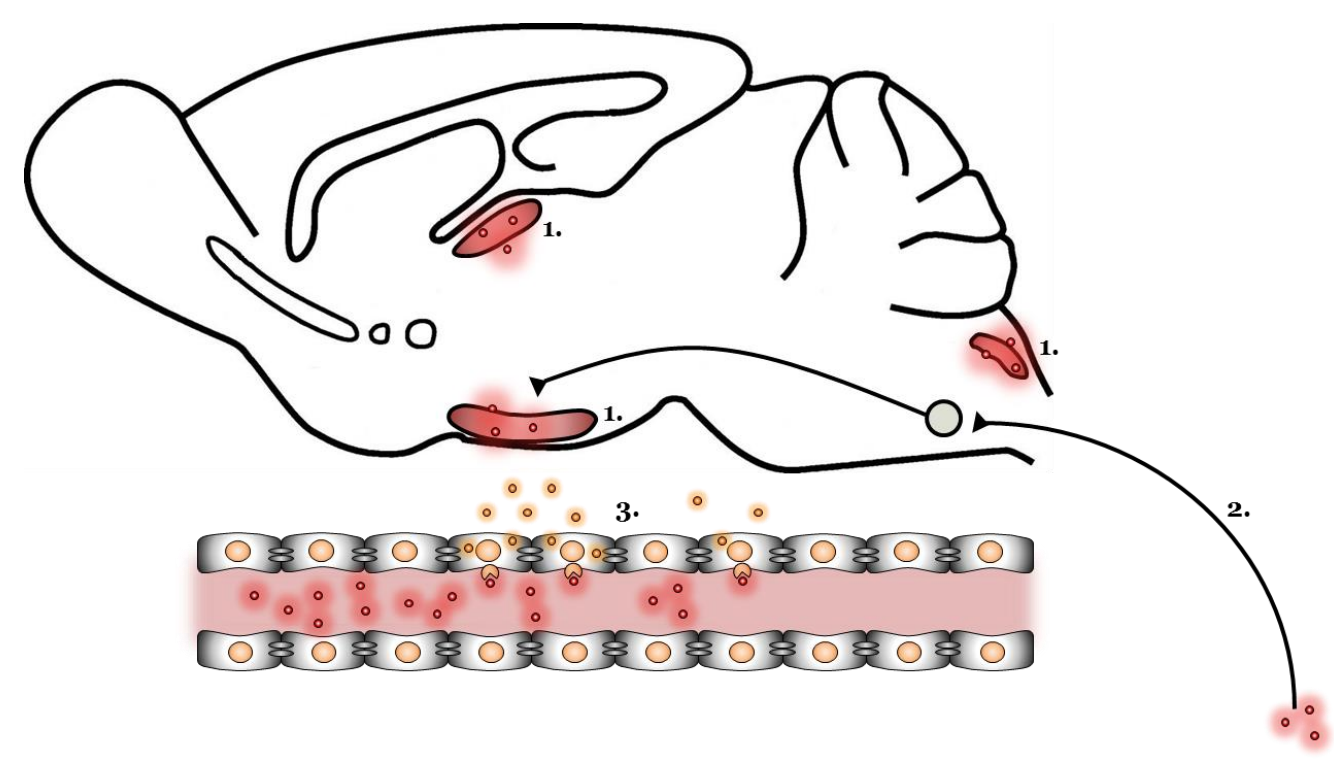

Figure 3. Suggested pathways for immune-to-brain signaling. 1. Cytokines and other inflammatory mediators have direct access to the brain through the circumventricular organs (CVOs). 2. Circulating mediators bind to receptors on peripheral nerves such as the vagus nerve that transmit the signal to the brain. 3. Cytokines bind to receptors on the endothelial cells in the blood-brain barrier, which produces prostaglandins that are released to the brain. For more details, see chapter Taking the signal from the periphery to the brain. Modified from Engblom et al 2002 [70]. 


\section{INTRODUCTION}

\section{Biosynthesis of prostanoids}

As has already been described, PGE2 plays an important role in mediating several brainelicited illness responses. It has long been known that pain and fever can be attenuated by the use of willow plants. Around 200 years ago, the active substance in these plants was shown to be salicylic acid, which is an active metabolite in Aspirin ${ }^{\circledR}$. The finding that aspirin acts by inhibiting prostaglandin synthesis has been credited to John Vane [81], a finding for which he was awarded the Nobel Prize in 1982. Prostaglandins as such was first found in seminal fluid and seminal vesicles [82] and are now known to be involved in myriads of processes, including muscle contraction and dilatation, pain, blood clotting, labor induction, hormonal regulation, kidney function and fever.

\section{Cyclooxygenases}

The source of prostaglandins is arachidonic acid, which is a component of the phospholipids in the cell membrane. Arachidonic acid is cleaved from the phospholipids by different phospholipase A2 (PLA2) enzymes [83] and constitutes the substrate for the COX-enzymes COX-1 [84, 85] and COX-2 [86, 87]. These enzymes convert arachidonic acid (AA) to the unstable prostaglandin endoperoxide H2 (PGH2), which then is converted by terminal isomerases into the different active prostanoids: PGD2, PGE2, PGF2 $\alpha$, prostacyclin (PGI2) and thromboxane (TXA2) (Figure 4). COX-1 is classically known as the housekeeping cyclooxygenase, and the prostanoids derived from COX-1 are mainly involved in homeostatic functions. COX-1 is constitutively expressed in almost all tissues and it is not up-regulated to any larger extent by specific stimuli [88]. COX-2, however, is normally not expressed during basal conditions, but is strongly up-regulated in response to pro-inflammatory cytokines [89-91] and the prostanoids derived from COX-2 are involved in mediating inflammation [92]. COX-2 expression is seen in most cell types responsive to inflammatory stimulation and central expression has been reported [93, 94] as well as expression in the brain endothelium [75]. 


\section{Terminal isomerases}

PGE2 is a critical mediator of many inflammatory symptoms. PGH2 is converted to PGE2 by three different PGE2 synthases (PGES): cytosolic PGES (cPGES) [95], microsomal PGES-1 (mPGES-1) [96] and microsomal PGES-2 (mPGES-2) [97] (Figure 4). cPGES and mPGES-2 are not affected by inflammation [98] and are constitutively expressed. These enzymes account for synthesis of PGE2 for homeostatic purposes and the expression is proposed to be coupled to COX-1 [99]. During inflammation, there is a strong up-regulation of mPGES-1 expression [74, 100] which produces the large amount of PGE2 that is involved in mediating symptoms such as fever, pain and lethargy. Upon inflammation, mPGES-1 has been shown to be co-expressed with COX-2 [95, 97]. The importance of mPGES-1 during inflammatory conditions is profound and includes involvement in fever [69] anorexia [101, 102] and malaise [103].

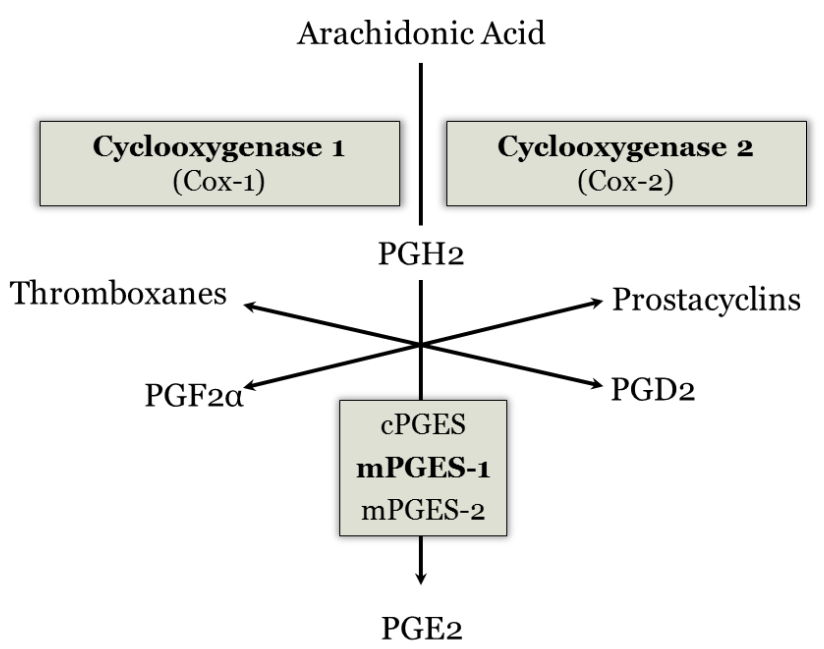

Figure 4. Biosynthesis of prostaglandins. See text for more details. 


\section{INTRODUCTION}

\section{Inflammatory anorexia}

Diminished appetite during illness, something that most persons have experienced, was described already during the $16^{\text {th }}$ century as:

"Nature, being desirous to preserve man as long as possible, teaches what rules to follow in time of illness; for she immediately deprived the sick of their appetite in order that they may eat but little-for with little, as it has already been said, Nature is content"

- Luigi Cornaro (1464-1566), The Art of Living Long. Milwaukee. Butler WF. 1917.

Anorexia can be defined as loss of appetite with an accompanying reduction of food intake, and can be seen during infection in a wide range of species [104]. Together with fever, fatigue and decreased interest in participating in social activities, anorexia is a hallmark of acute infectious diseases. Reduced food intake is believed to have several benefits since it i) prevents further ingestion of potentially contaminated food [105]; ii) reduces the organism's motivation to seek food and thereby prevents spreading of the disease to others, and, at the same time, avoids that the organism itself becomes an easy pray for predators during its search for food; iii) shunts the use of energy storage to be used by the immune system rather than for food-associated activities such as food search and digestion; and iv) reduces the nutrient content, and especially iron, in the circulatory system, which will result in diminished growth and reproduction of microorganisms [106-108]. Anorexia has been shown to be of great importance for the survival of an organism. Already 35 years ago, it was shown that developing anorexia in response to disease was crucial for survival, since mice subjected to infection and forcefed had both a more rapid disease progress and a higher mortality rate than mice fed $a d$ libitum (free fed) [109]. Along with these findings, it has been shown that pre-starved mice have a higher survival rate than mice fed ad libitum during infection [110]. 


\section{Cachexia}

While the benefits of anorexia during acute infections are proven and appear biologically adaptive, the benefits of reduced food intake during chronic inflammation and diseases are not as obvious. Loss of appetite is a common symptom in patients with chronic diseases such as cancer, AIDS and tuberculosis and studies have reported that 50-90\% of all cancer patients show weight loss [111-113].

In contrast to what Cornaro observed 550 years ago, Hippocrates wrote more than 2400 years ago:

"The flesh is consumed and becomes water...the abdomen fills with water, the feet and legs swell, the shoulders, clavicles, chest and thighs melt away...The illness is fatal." [114]

The illness Hippocrates is referring to is cachexia. Cachexia is a pathological state of malnutrition in which reduced appetite is associated with an increased metabolic rate and wasting of lean body mass [115-117]. The weight loss in cachexic patients differs from the weight loss in patients suffering from anorexia nervosa, since loss of weight during starvation is mostly due to loss of fat-tissue, while cachexia results in equal loss of fat- and muscle-tissue [118]. Chronic starvation seems to be more adaptive since, in concordance with the reduced food intake, the basal metabolic rate is reduced as the body attempts to conserve energy. In cancer patients, the energy expenditure following reduced food intake has been reported to be reduced, normal or increased [115] illustrating the complex metabolic dysregulation that occurs in these patients. As a consequence of reduced food intake but not by proxy-reduced metabolism, it is a common finding that tumor-bearing animals die from cachexia and exhaustion of metabolic fuels rather than from metastasis or infection [119-121], and in patients it has been suggested that $20-30 \%$ of all deaths from cancer are actually caused by cachexia [122]. However, increased appetite does not seem to reverse the cachexic syndrome. Improvement of appetite by treatment with medroxyprogesterone acetate did not result in weight gain in patients with malignant cancer [123] and it was shown that most of the weight gain seen in that study was due to increase of adipose tissue and water [124]. The 


\section{INTRODUCTION}

changes in metabolism and tissue catabolism in cancer patients are extensive (see [125]), but the cause leading to the metabolic changes as well as the cause of appetite suppression are poorly understood. There are suggestions that the tumors send out factors that act on hypothalamic structures in order to suppress appetite [115] and several cytokines that are normally seen during the acute phase response, for example IL-1 $\beta$, TNF- $\alpha$, IL- 6 and interferon $\gamma$ (IFN- $\gamma$ ) have been shown to be up-regulated or involved in suppression of appetite during cancer [115].

\section{Anorexia-cachexia}

As already been mentioned in previous sections, LPS binding to TLRs will recruit the MyD88 complex to activate NF- $\mathrm{kB}$ with subsequent transcription of pro-inflammatory cytokines. Cytokines are the mediators of the inflammatory symptoms seen during infection, and many of them have been examined for their ability to induce anorexiacachexia. Increased levels of cytokines have also been shown in patients with malignant tumors and it has been proposed that tumors have the ability to release cytokines [126]. Almost 30 ago it was shown that IL-1 $\beta$ is a potent mediator of anorexia [127]. Both peripherally and centrally administered IL-1 $\beta$ has been shown to have the ability to evoke anorexia [128] and this effect has been attributed to PGE2 [129].

The mechanisms mediating inflammatory-induced anorexia are still not completely elucidated, but they have been suggested to involve PGE2, since both peripheral and central administration of PGE2 will generate anorexia in rodents [130-134]. PGE2 is produced by the enzymes COX-2 and mPGES-1, both of which have been shown to be involved in mediating inflammatory-anorexia. Several studies have shown that treatment with un-specific COX-inhibitors attenuates anorexia [135-141], and this effect seems to be mediated by $\mathrm{COX}-2$, since specific COX-2 inhibitors to a great extent mimics the effect of un-specific inhibitors [142, 143]. Supporting the importance of PGE2 signaling, deletion of the terminal enzyme mPGES-1 was shown to attenuate IL$1 \beta$-induced anorexia in mice $[101,144]$. These events seem to originate from central pathways, since inhibition of COX-2 in dorsal and median raphe nuclei in the brain stem largely reduced LPS-induced anorexia in rats [145] The importance of central signaling is emphasized by studies demonstrating that increased levels of PGE2 could be seen in 
CSF, but not in plasma after peripheral administration of LPS [143]. In line with these data it was shown that COX-2 was induced in the brain endothelium, but not in the brain parenchyma in mice after peripheral administration of IL-1 $\beta$ or LPS [146], and the time course of that event was parallel to decreased intake of sweet milk, suggesting that COX-2 in the endothelial cells of the blood-brain barrier might play an important role in transmitting the anorectic signal from periphery to the brain.

It has been proposed that LPS together with cytokines from the perivascular cells in the blood-brain barrier stimulates endothelial cells to produce PGE2 [147] that can be released into the brain parenchyma and bind to receptors on neuronal cells. PGE2 acts by binding to one of four receptors, EP1-4, which are all expressed in the brain at sites known to be activated during systemic inflammation [148-151]. All receptors mediate different behavioral responses during systemic inflammation and the sites of expression in the brain are in concurrence with the behavioral effects proposed to be elicited by the different receptors. EP1 has been shown to be involved in inflammation-induced aversion [103] and impulsive behavior during stress [152], suggesting a role for EP1 in social behavioral changes seen during inflammation. The $\mathrm{EP}_{3}$ receptor is known to mediate fever [153-156] and EP2 signaling seems to be involved in hyperalgesia during systemic inflammation [157]. The most interesting PGE2 receptor in regard to regulation of food intake is the $\mathrm{EP} 4$ receptor. It has been shown that an $\mathrm{EP} 4$ antagonist inhibits anorexia mediated by centrally administered PGE2, and an EP4 agonist was found to reduce food intake in mice [133], which indicate that EP4 receptors are involved in signaling of inflammatory anorexia. 


\section{INTRODUCTION}

\section{Centrally activated pathways mediating anorexia during systemic inflammation}

Illness-induced anorexia in not solely mediated by the immune system. To mediate suppression of food intake, central pathways need to be activated. The central pathways used for suppressing appetite during infection are to a large extent the same as those that suppress appetite during physiological conditions, and the primary targets are the hypothalamus and the brainstem. NF- $\mathrm{BB}$ (a marker for inflammation) is actually induced exclusively in these regions during systemic inflammation [158]. Cells in these regions are susceptible to and have been shown to express receptors for inflammatory mediators such as IL-1 $\beta$ [159-161]. Several studies have demonstrated that leptin is both regulated by and have the capacity to regulate inflammatory mediators [128, 162-165]. It has been shown that peripheral administration of LPS induced leptin mRNA in adipose tissue and this expression is parallel to the suppression of food intake [163]. IL-1 $\beta$ and leptin seem to have a symbiotic relation. Thus, blockage of the expression or action of IL-1 $\beta$ attenuated the anorectic response after leptin administration [128] and hypothalamic expression of IL-1 $\beta$ is regulated by leptin [164].

In line with the hypothesis that it is the same cells that mediate suppression of food intake during normal- and pathological conditions, the melanocortin system in general, and the $\mathrm{MC} 4-\mathrm{R}$ in particular, has been shown to be directly involved in mediating inflammatory anorexia [27, 166-168]. MC4- $\mathrm{R}$ is strongly expressed in both the parabrachial nucleus in the brain stem [169] and in the PVH [170] in cells responsive to immune and aversive stimuli. The anorexic effect of LPS and IL-1 $\beta$ can be attenuated by $\mathrm{MC} 4-\mathrm{R}$ - antagonists $[167,171]$ and mice lacking expression of $\mathrm{MC} 4-\mathrm{R}$ do not develop LPS- or tumor-induced anorexia [166]. 


\section{Taste aversion during inflammation}

In the first section of this introduction I wrote that hunger sensation is a subjective feeling and includes factors, such as environment, culture and genetics, but the involvement of these and other conditioned behaviors are outside the scope of this thesis. This was not completely true.

It is common that patients undergoing radiation- or chemotherapy report loss of appetite, altered taste sensations and aversion to food [172, 173]. Also inflammation has been shown to affect taste preferences [174] and the motivation to seek food [175]. These findings can be coupled to the behavior of avoiding food that has previously been associated with unpleasantness, a behavior that can be seen in many species. The purpose of this adaptive behavior is to avoid things that have the potential of making us ill; this behavior is called conditioned taste aversion (CTA). In the case of the cancerpatients, it is not the food that causes them to feel ill, but the natural response is nevertheless to avoid food.

Aversive stimuli such as lithium chloride (LiCl) and LPS induce activation of neurons in the parabrachial nucleus of the brain stem co-expressing $\mathrm{MC} 4-\mathrm{R}$ and calcitonin generelated peptide (CGRP) [169]. These cells project to the amygdala where they have been shown to mediate appetite suppression; inhibiting these cells induces feeding during aversive conditions [176]. However, inhibiting CGRP-neurons in PB did not entirely abolish LiCl-induced CTA [177], and other nuclei such as NTS and the CVO area postrema have been proposed to also play a role in acquiring CTA [177]. Thus, the central pathways for CTA are tightly linked to those of energy balance regulation and might relate to anorexia. Currently, the only thing we know regarding this is that CTA is not the sole contributor to inflammation-induced anorexia [178]. 


\section{AIM}

The general aim of the research leading to this dissertation was to investigate the underlying mechanisms behind inflammation-induced and cancer-induced anorexiacachexia with specific focus on the involvement of prostaglandin-mediated pathways.

\section{Specific aims}

to investigate the role of prostaglandin E2 synthesizing enzymes and PGE2 in initiating and maintaining loss of appetite and body weight during tumor growth in mice (paper I)

$>$ to elucidate the involvement of MyD88 in different cell types and tissues during inflammation-induced and tumor-induced anorexia (paper II)

$>$ to determine which of the PGE2 receptors that is critical for the anorexic response evoked by peripheral immune challenge (paper III)

$>$ to elucidate which cell population that express COX-2 critical for mediating anorexia upon peripheral immune challenge (paper IV)

$>$ to demonstrate to which extent fever and anorexia are mediated by prostaglandin synthesis in the same cell population or if they are mediated by distinct pathways (paper IV) 


\section{METHODS}

\section{Transgenic mouse models}

For this thesis, mice lacking endogenous expression of a gene of interest and mice with conditional knock-out of genes have been used in the studies on which all four papers are based. The transgenic mice used in the research for this thesis were either purchased from repositories and brought to the laboratory for further breeding or were provided as a gift from the laboratory where the mouse-line had been generated.

Basically a modified, non-functional, version of the DNA sequence encoding the protein of interest is incorporated in the DNA using an endogenous system in the cell called homologous recombination that in a normal cell enables the cell's chromosomes to exchange genetic information during cell division. The DNA with the modified genome is transfected into embryonic stem cells that in turn are injected into a blastocyst, and implanted in a surrogate mother. The offspring will carry the disrupted gene in their germ cells thus enabling it to be further transferred through breeding. This will eventually lead to mice carrying two copies of the disrupted gene, hence no expression of the protein or expression of a non-functional protein, a so called knock-out mouse.

Knock-out is a very powerful and useful tool to use in assessing the function of a protein, but this technique comes with some drawbacks. Depending on which protein is knocked-out the approach can cause a high motility rate in the offspring due to loss of function in mechanisms important for early development. Another issue is that embryonic knock-out can cause compensatory mechanisms to maintain the function of the proposed knock-out protein, leading to an artificial pathway instead of loss-offunction. 
To circumvent these processes there are mouse-models with conditional knock-outs of genes. For the studies leading to this thesis conditional knock-outs were generated by the Cre-loxP recombination technique. Cre-loxP recombination allows site specific disruption of a specific gene $[179,180]$, by using a mouse that has the gene of interest flanked by small DNA sequences, called loxP sites, on each side. The gene that is flanked by loxP sites is often referred to as floxed (flanked by loxP). The mouse line carrying the floxed gene is crossed with a mouse expressing Cre recombinase under a cell-type specific promoter. The Cre enzyme will recombine DNA between the loxP sequences, causing the DNA flanked by loxP to be either deleted or inverted, depending on the direction of the loxP sites.

The Cre-loxP technology provides a powerful tool for examination of site-specific functions of genes. As an extension of this technique, it is possible to switch genes off and on by expressing Cre in an inducible manner. This makes it possible to further examine the specific function of a gene at a given time point. It also prevents compensatory mechanisms from occurring, and it is possible to delete genes that have diverse effects in the juvenile and adult mouse. Inducible Cre was used in papers II and IV. In paper IV, we used the CreER ${ }^{\mathrm{T} 2}$ technology, where Cre recombinase is combined with an estrogen receptor. By injecting a ligand for this receptor (tamoxifen) the Cre recombinase gets activated and translocated into the nucleus to induce recombination. In paper II, we also induced Cre expression by poly I:C, which is a synthetic double-stranded RNA that induces high levels of interferons. The Cre recombinase used in the study for paper II (MX1) was designed in such a way that it not expressed in healthy mice, but becomes induced upon inflammation, and specifically by interferon induction, hence activated by poly I:C. It is important when using these types of inducible Cre-techniques to both allow the recombination to get sufficient time to occur effectively and to wash-out the acute effects of the injected ligands. We therefore waited between 3-5 weeks between injections and experiment to be sure that we did not have any confounding factors resulting from injections or insufficient recombination. 
When using Cre-lox technology it is crucial to evaluate the model to know if the recombination has occurred and how effective it is. It is very rare that it is complete, which would mean that $100 \%$ of the cells supposed to be targeted are in fact targeted. The recombination efficiency is put in proportion to the response that is seen, and evaluated to determine if the lack- or attenuation of the response is due to the recombination or not. For all the lines used in these studies, there are results from our own or other groups confirming that the recombination is sufficient to evoke a response in a mouse model.

\section{Acute inflammation models (paper II-IV)}

Two different inflammatory stimuli were used to conduct the experiments on acute inflammation; in paper II and IV, LPS was used and for paper III, IL-1 $\beta$ was used. Both these stimuli elicit an inflammatory response lasting for approximately 12-hours after intraperitoneal injection.

LPS is a component in the cell wall of gram-negative bacteria, and is used because it can trigger an immune response involving several cytokines and inflammatory pathways used by the innate immune system; it is commonly used in inflammatory models in rodents. Although LPS is a good, standardized and reproducible model for several inflammatory conditions, it does not fully mimic the complexity of infection in humans. Its simplicity, however, makes LPS a useful tool for studying such conditions, since it can offer a good basis for providing candidate targets.

To study the effect of specific cytokines, the cytokine itself can be injected into the animal to induce an immune response. We have seen that IL-1 $\beta$ triggers brain-mediated illness responses that cannot be evoked by, for example TNF- $\alpha$ or IL-6. In paper III, IL-1 $\beta$ was used as an inducer of anorexia. The reason for using a different inflammatory model in this study was that this study is a continuation of a study previously done in the laboratory in which it was shown that mice lacking the terminal enzyme for PGE2 production (mPGES-1) were protected from developing anorexia after IL-1 $\beta$, but not after LPS [144]. Using a single cytokine is, however, somehow artificial. Inflammation is a complex event, and the use of a single cytokine rarely fully mimics the natural 


\section{METHODS}

response, but its use is valid for studying the involvement of the cytokine itself in different responses. However, one should be aware that many responses occur due to interactions between cytokines and removing the other elements of the event can lead to results that are not related to the true physiological response.

\section{Anorexia model (paper I-IV)}

All food intake recordings were conducted during the dark phase, i.e. between 7 p.m. and 7 a.m. Mice were placed in individual cages five days before experiment onset in order for them to be able to acclimatize. At experimental onset, the mice were given an intraperitoneal injection of an inflammatory stimulus (LPS or IL-1 $\beta$ ) and food was withdrawn for one hour. Food was then reintroduced and weighed four-, seven, and 13 hours after injection. At each time point, the floor of the cage was checked for food spillage. In the tumor model, mice were housed in cages with grid floors, allowing spillage to be collected and measured. This is a very simple and effective way for measuring food intake. The results are highly reproducible, and this procedure makes it possible for many mice to be tested at the same time. All mice were only injected once with LPS or IL-1 $\beta$. Multiple injections of LPS cause desensitization [181], which will influence the food intake greatly.

An automatic system for measuring food intake was used in paper I and paper III. By using this system, we could make an extended analysis of the food intake, including not only the amount of food ingested at a certain time point, but also of the meal pattern, which made it possible to assess the feeding behavior in these specific experimental groups. 


\section{Tumor model (paper I and II)}

The tumor-model used in these studies was of the MCG 101-type. This was originally described as a sarcoma [182], but is nowadays considered to be an epithelial-like solid tumor. Fragments were bilaterally implanted subcutaneously on the back of the mice using a needle with trocar tip. The tumor grows in a rapid and highly reproducible way causing $\mathrm{C}_{57} \mathrm{BL} / 6$-mice to display a significant decrease in food intake seven days after tumor implantation compared to the sham-implanted controls. This anorexia is progressive and at day 12-15 after tumor-implantation mice will die due to cachexia [182]. The tumor-model has been used in vivo for more than 30 years, and it results in loss of food intake that is highly consistent between the studies [183-187].

\section{Body temperature recordings (paper I and IV)}

Body temperature was measured using a telemetric system. Mice were implanted with a transponder in the abdominal cavity, transmitting the core body temperature of the animal to a receiver that is located under the mice's home cages. The signal is sent to a computer, collecting the body temperature over time. This set up provides very little stress to the animals, since everything is done in their home cages with as little handling as possible. The only time when the animals need to be handled during the experiment is during the i.p. injection, hence all graphs of body temperature have a "stress-peak" lasting around 30 minutes to one hour after injection. 


\section{METHODS}

\section{Conditioned taste aversion (paper IV)}

In paper IV, we investigated the extent to which taste aversion contributes to anorexia. For this, we set up a model for conditioned taste aversion (CTA) based on a study by Morméde et al. [188]. The mice were water deprived at the onset of the dark period and for the following four hours. This was followed by one hour access to a $0.15 \%$ saccharin solution, followed by an injection of LPS. This makes the mice associate the sweet taste of the saccharin with feeling ill, and we thereby accomplished a conditioned taste aversion. Mice were first habituated to only water deprivation for one week. On the first day of the experiment, mice were water deprived for four hours followed by access to saccharin for one hour and were thereafter injected with LPS or saline. This day is referred to as the "training day" (Figure 5). On day four, referred to as the "test day", mice were water deprived for four hours followed by one hour access of saccharin. If conditioning is established, mice treated with LPS on training day drink less saccharin than mice receiving saline on training day.

As for all experiments involving LPS or other inflammatory stimuli, there must be sufficient time for the stimulus to be completely washed out. For this experiment, the wash-out period was two days (Figure 5). During the establishment of this experiment, we also tested giving the mice two training sessions before the test. This additional training session did not result in a stronger conditioning, leading us to choose only one training session. Also, while establishing the method, we compared how much water the mice drank after being deprived of water for four hours. We examined water consumption both 30 minutes after water reintroduction and one hour after, and based on these measurements, we chose one hour. 


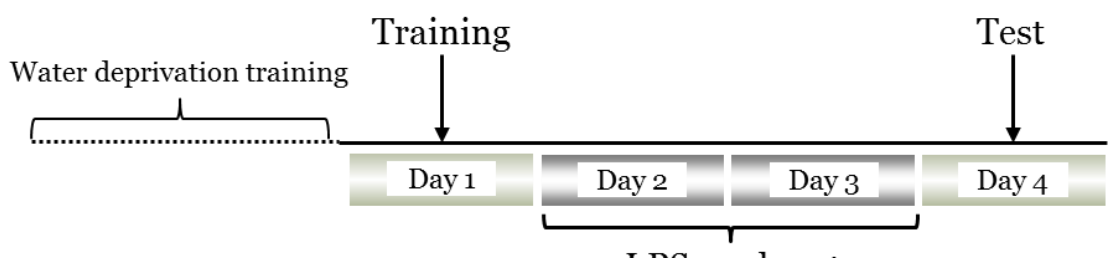

LPS wash out

Figure 5. The CTA schedule. On training day, mice were water deprived for four hours followed by access to $0.15 \%$ saccharin solution for one hour, and thereafter injected with LPS. On test day, mice were water deprived for four hours followed by one hour access to saccharin.

\section{PGE2 analysis (paper I)}

In the study for paper I, levels of PGE2 were measured in plasma and cerebrospinal fluid. For plasma collection, mice were killed with $\mathrm{CO}_{2}$ and blood was collected from the heart into EDTA-coated tubes. The samples were centrifuged at $7000 \mathrm{~g}$ at $4^{\circ} \mathrm{C}$ for seven minutes and the plasma was collected and stored at $-80^{\circ} \mathrm{C}$. Cerebrospinal fluid was collected from cisterna magna by mounting the mice in a stereotaxic frame and extracting the CSF with a Hamilton syringe under microscope guidance. Samples were immediately frozen on dry ice and stored at $-80^{\circ} \mathrm{C}$. For determination of PGE2 levels in plasma, an EIA kit measuring PGE2 metabolites was used. Due to the fast degradation of PGE2 in plasma, it is not possible to measure PGE2 per se in a credible manner, which is why the kit instead converts the PGE2 metabolites into a single stable form that can be detected by EIA. As a complement, PGE2 levels as such were measured in plasma using Luminex ${ }^{\circledR} \mathrm{xMAP}^{\circledR}$ system. PGE2 levels in CSF were analyzed by EIA. The degradation of PGE2 in CSF is much slower that in plasma, which is why it is possible to use EIA for this specific purpose. 


\section{Gene and protein expression}

In paper I, gene expression of the prostaglandin E2 receptor-4 in the hypothalamus was analyzed. The mice were killed with $\mathrm{CO} 2$ and the hypothalamus was dissected and mRNA expression was analyzed using RT-PCR and qPCR using TaqMan ${ }^{\circledR}$-assays. These techniques provide a powerful tool for amplifying and quantifying gene expression by transcribing mRNA to cDNA, which provides the input material to the real-time PCR, in which the DNA is amplified and quantified by fluorescence.

There are two commonly used ways to analyze the expression, relative and absolute. In this thesis it is the relative expression that is reported. This means that the expression of the copy number of the gene of interest is estimated relative to the expression of a so called house-keeping gene that should be ubiquitously and constantly expressed. $G A P D H$ was used as the house-keeping gene and expression was calculated using the comparative $\mathrm{Ct}_{\mathrm{t}}{ }^{(2-\Delta \Delta C \mathrm{Ct})}$ method, which calculates changes in gene expression as a relative fold difference between an experimental sample and the house-keeping gene. When measuring the absolute expression a standard curve with known concentration is used. Both absolute and relative quantification of expression are well-recognized and frequently used methods in research studies, and both methods have their drawbacks. When investigating relative expression, it is important to use house-keeping genes that are validated to be constantly expressed in the tissue from which the RNA is extracted. Due to the relative comparison it is more difficult to compare the results from different plates. Absolute quantification assumes that all standards and sample have the same amplification efficiency, which is not always the case. It is also important to create reliable standards to be able to compare results from different plates. 


\section{COX-inhibitors and PGE2 neutralization (paper I and IV)}

The administration route of a drug is crucial if it is to work properly. For studying its effect on the acute response after LPS, the drug is usually given intraperitoneally at an appropriate time-point before the immune challenge. The time-point at which the drug is given is based on the pharmacodynamics of the drug, and the concentration is titrated to be the lowest at which a sufficient inhibition can occur. In paper IV, we used the general COX-inhibitor indomethacin, the specific COX-1 inhibitor SC-560 and the specific COX-2 inhibitor parecoxib. All drugs were given 30 minutes before LPS administration and parecoxib was additionally administered after four hours due to the fast dynamics of its effect. Indomethacin and parecoxib were given i.p. while SC-560 was given orally. This difference depends on the fact that it is difficult to dilute SC-560 in saline, so SC-560 was instead diluted in a mixture of methylcellulose and tween 80 and given by oral gavage.

For the experiments with tumor-bearing mice described in paper I, all drugs except for SC-560 were administered with the drinking water, while SC-560 was administered in specially prepared food pellets, which results in more stable concentrations of the drugs in the animals than if they were to be given injections every 12-hours. PGE2 neutralization with an antibody (2B5) was given i.p. to tumor-bearing mice after two consecutive days of anorexia.

\section{Statistics (paper I-IV)}

Data are presented as mean \pm SEM. When comparing two groups, a two-tailed unpaired $t$-test was used, and when comparing three or more groups, we used one-way, two-way or two-way repeated measures ANOVA followed by Tukey's or Bonferroni's post hoc test or a $t$-test at each time-point. $P$ value $<0.05$ was considered significant. 


\section{SUMMARY OF THE PAPERS}

\section{Paper I}

AIM: to investigate the role of PGE2 synthesizing enzymes and PGE2 in initiating and maintaining loss of appetite and body weight during tumor growth in mice.

\section{Findings:}

$>$ Un-specific inhibition of COX-enzymes attenuates tumor-induced anorexia.

$>$ Inhibition of COX-1 delays onset of tumor induced anorexia.

$>$ Inhibition of COX-2 does not prevent mice from developing tumor-induced anorexia.

$>$ mPGES-1 is not involved in tumor-induced anorexia.

$>$ PGE2 is elevated in plasma but not in the cerebrospinal fluid in tumor-bearing mice.

Conclusion: Onset of cancer anorexia is dependent on COX-1 signaling but PGE2 is not crucial for mediating anorexia in tumor-bearing mice. 


\section{Paper II}

AIM: to elucidate the involvement of MyD88 in different cell types and tissues during inflammation-induced and tumor-induced anorexia.

\section{Findings:}

> Cell-specific deletion of Myd88 in brain endothelial cells and neural cells does not attenuate inflammation-induced anorexia.

$>$ Deletion of the gene for MyD88 prevents mice from developing LPS-induced anorexia and transplantation of WT bone marrow to MyD88 KO mice reestablishes anorexia after LPS administration.

Cell-specific deletion of MyD88 in hematopoietic- or myeloid cells attenuates LPS-induced anorexia and tumor induced anorexia and abolishes loss of body weight in tumor-bearing mice.

Conclusion: LPS- and cancer-induced anorexia can be largely attributed to expression of MyD88 by cells from the hematopoietic- and myeloid linage.

\section{Paper III}

AIM: to determine which of the PGE2 receptors is critical for the anorexic response evoked by peripheral immune challenge.

\section{Findings:}

Mice with deletion of either of the EP-receptors show intact anorexia.

> Involvement of PGE2 in peripherally evoked anorexia is strain dependent.

Conclusion: A solitary EP-receptor does not seem to be mediating IL-1 $\beta$-induced anorexia. However, the involvement of PGE2 in inflammatory anorexia in mice is strain dependent, and PGE2 expression in the same strain as the strain in which the EPreceptors were deleted is not involved in IL-1 $\beta$-induced anorexia. 


\section{Paper IV}

\section{AIMS:}

$>$ to identify the cell population in which COX-2 is critical for mediating anorexia upon peripheral immune challenge.

$>$ to demonstrate the extent to which fever and anorexia are mediated by the same cell population or if they are mediated by distinct pathways.

\section{Findings:}

> Cell-specific deletion of COX-2 in brain endothelium, neuronal cells or myeloid cells does not prevent mice from anorexia after peripheral injection of LPS.

$>$ LPS-induced fever is greatly attenuated in mice with cell-specific deletion of COX-2 expression in brain endothelial cells, but un-affected in mice with cellspecific deletions of COX-2 in neuronal- and myeloid cells.

Conditioned taste aversion is un-affected by inhibition of COX-enzymes.

Conclusion: Anorexia and fever are mediated by distinct pathways and conditioned taste aversion is one of few brain-mediated inflammatory symptoms that is prostaglandin independent. The cell type expressing the COX-2 crucial for anorexia is still not identified, but brain endothelial cells, neuronal cells and myeloid cells can be excluded as solitary sources. 


\section{RESULTS \& DISCUSSION}

\section{Paper I}

\section{Background/Aim}

Inflammatory processes have been shown to be of great importance for the development of cancer-induced anorexia-cachexia [183]. Prostaglandins are known to affect tumorigenesis and have been proposed to be involved in the development of anorexiacachexia $[187,189]$. Acute inflammatory anorexia has been shown to be dependent on COX-2 signaling, but the involvement of the COX-enzymes and the mediators that these produce have not been investigated in the context of cancer-induced anorexia-cachexia. Of particular interest is PGE2, since it has been suggested to be involved in acute inflammatory anorexia $[101,144]$. In this study, we therefore wanted to investigate the role of PGE2 and the PGE2-synthesizing enzymes COX-1, COX-2 and mPGES-1 in cancer-induced anorexia-cachexia.

\section{Tumor-bearing mice have decreased meal frequency}

Meal pattern analysis showed that tumor-bearing mice had decreased meal frequency compared to sham-implanted controls, but meal size and duration were slightly increased compared to controls. This effect is similar to what causes decreased food intake during systemic inflammation by LPS [140] or sickness behavior evoked by $\mathrm{LiCl}$ [190] and indicates that decreased food intake in cachexia does not involve delayed gastric emptying, since the tumor-implanted mice could eat meals of the same size as sham-implanted mice. 


\section{RESULTS \& DISCUSSION}

The onset of cancer-induced anorexia is COX-1 dependent but prostaglandin E2 does not seem to have effects on food intake suppression seen in tumor-bearing mice

The unspecific COX-inhibitor indomethacin attenuated the anorexia and tumor growth. The appetite restoring effect can be attributed to indomethacin having a direct effect on signaling to or in the brain, rather than just inhibiting tumor growth, since giving indomethacin after anorexia onset still rescued food intake but without affecting tumor growth. We could demonstrate COX-2 expression in the blood vessels of the brain in tumor-bearing mice, but pharmacological inhibition or COX-2 did not affect tumor growth or anorexia development. Pharmacological inhibition of COX-1 delayed anorexia onset and reduced circulating PGE2 levels to sham control levels, suggesting that COX-1 might play a role in initiation of the anorexia. However, no COX-1 mRNA up-regulation could be detected in concordance with reduced food intake in tumor-bearing mice.

Analysis of PGE2 levels in plasma and cerebrospinal fluid showed that PGE2 was strongly up-regulated in plasma from tumor-bearing mice, but no differences could be detected in the cerebrospinal fluid. This complies with the finding that these mice are afebrile, since fever is strongly dependent on PGE2 induction in the brain [69]. It also indicates that PGE2 does not cross the blood-brain barrier to reach target structures within the brain. Finally, we could show that deletion of mPGES-1 or the prostaglandin E2 receptor proposed to mediate the anorexigenic properties of PGE2 in an acute model for anorexia did not influence any aspects of the anorexigenic response in the tumorbearing mice.

Taken together, these results demonstrate the involvement of COX-1 in anorexia onset in tumor-bearing mice. Unselective COX-inhibition strongly attenuated the anorexigenic response and tumor growth, and this effect was not due to PGE2, since deletion of mPGES-1 did not influence anorexia development. Involvement of other PGESs is not likely since PGE2 in the cerebrospinal fluid was un-affected by the tumor and peripheral treatment with a PGE2 antibody to inhibit circulating PGE2 did not affect anorexia development. A question that remains to be answered is what specific prostanoid is involved in tumor-induced anorexia. The answer to this is not obvious, since the prostanoids reported to have anorexigenic properties are not that well 
characterized. The prostanoid that is the best characterized in regard to its anorexigenic properties is PGF2a [191, 192]. However, the anorexigenic properties of PGF2 $\alpha$ are short lived [192], and this prostanoid has also been shown to be involved in muscle anabolism [193], which is in sharp contrast to the muscle wasting seen during cachexic disease states.

Regarding the finding that COX-1 is involved in anorexia onset, it has been shown that COX-1 can drive inflammation, and that the early release of corticosterone, an immune suppressor released by the adrenal glands in response to stress, is COX-1 dependent, whereas late release is dependent on COX-2 [194]. These results are in line with our finding that COX-1 seems to initiate the response. COX-1 has also been shown to be expressed during inflammation in areas such as the vagus nerves [63], the blood-brain barrier and microglia [195], all with the potential for mediating immune-to-brain signaling and subsequent anorexia.

\section{Paper II}

\section{Background/Aim}

MyD88 is an intracellular adapter protein for Toll-like receptor-4, which is the receptor binding to LPS. Binding of LPS to MyD88 will activate transcription factors such as NF$\kappa \mathrm{B}$ and subsequent transcription of pro-inflammatory genes such as IL-1 $\beta$, TNF- $\alpha$ and IL-6. It is known that deletion of the gene encoding MyD88 prevents inflammatoryinduced, as well as tumor-induced anorexia in mice [183, 196]. In this study we investigated the cellular origin of the MyD88 expression that mediates anorexia in both a model for acute anorexia and a model for tumor-induced anorexia.

\section{MyD88 signaling in hematopoietic/myeloid cells is involved in LPS-induced anorexia}

As we have seen before, deletion of MyD88 inhibits anorexia after peripheral administration of LPS in mice. This was not seen when deleting MyD88 specifically in the brain endothelial cells, or in neural cells, since mice lacking MyD88 expression in these cell populations did not differ in the anorexia response compared to their littermates. These finding are in good concordance with the findings that mice lacking 


\section{RESULTS \& DISCUSSION}

TAK-1, another intracellular activator of NF- $\mathrm{BB}$, have normal anorexia in response to peripheral immune challenge, thus suggesting that these cells are not involved in mediating anorexia [78].

By using chimeric mice, we were able to show that LPS-induced anorexia was reestablished in MyD88 KO mice that had been transplanted with WT bone marrow, thus expressing MyD88 in hematopoietic cells but not in non-hematopoietic tissues. Hence, MyD88 expression in hematopoietic cells is important in mediating LPSinduced anorexia. The next step was to investigate if we could reproduce these findings in mice with a genetic deletion of MyD88 in hematopoietic cells, and indeed we could. Mice lacking MyD88 in hematopoietic cells or myeloid cells had a strong attenuation of the anorexigenic response. The Cre-line we used for deleting MyD88 in hematopoietic cells has been shown to recombine in hepatocytes as well, and we therefore examined if this cell population was involved in LPS-induced anorexia, but it was not. The food intake was measured 4, 7, 13 and 22 hours after LPS injection, and the attenuation of anorexia seen in mice lacking MyD88 in hematopoietic/myeloid cells was first observed at the 7 hour check-point, suggesting that MyD88 expression in these cells is not involved in the initial phases of anorexia.

Tumor-bearing mice lacking MyD88 in hematopoietic cells had attenuated anorexia compared to WT mice. These mice also had a significantly reduced drop in body weight compared to WT mice implanted with tumors, suggesting that the metabolic changes underlying cachexia is in part abolished in these mice. This is of great importance since wasting is such a large part of the cachexia and is a part of the cachexia that has been shown to be very difficult to abolish [125]. 


\section{Paper III}

\section{Background/Aim}

It is well known that peripheral administration of IL-1 $\beta$ results in reduced food intake in rodents. This has been reported to be dependent on the action of COX-2 and mPGES-1. Thus inhibition of COX-2 [142, 143] and deletion of the gene encoding mPGES-1 [101, 144] prevents mice from developing anorexia upon peripheral administration of IL-1 $\beta$. These findings indicate that formation of prostaglandins in general and PGE2 in particular, is crucial for IL-1 $\beta$-induced anorexia to take place. PGE2 binds to one of four receptors, EP1, EP2, EP3 or EP4. Intracerebroventricular injections of agonists and antagonists for the different receptors in mice indicated that EP4 is the PGE2 receptor mediating the anorexigenic properties of PGE2, but this has not been confirmed in a setting where an inflammatory stimulus is administered peripherally. Hence, the aim of this study was to determine which of the EP-receptors mediates anorexia after peripheral immune challenge.

\section{Mice with deletion of either of the EP-receptors show intact anorexia}

We found that deletion of either of the EP-receptors did not prevent mice from suffering from anorexia after intraperitoneal injection of IL-1 $\beta$. Given that KO of mPGES-1, and subsequent prevention of formation of PGE2, strongly attenuate IL-1 $\beta$-induced anorexia, it was very surprising that none of the PGE2 receptors seemed to be involved. This result can mean two things: i) PGE2 binds to an as yet unidentified receptor in the brain or deletion of only one of the receptors is not sufficient to prevent anorexia, or ii) there is something strange going on in the model. Given the results from Ohinata et al., which showed that anorexia mediated by PGE2 could be prevented by antagonizing EP4 receptors and that agonizing the receptor reduced food intake in mice [133], the hypothesis that there is a unidentified receptor for PGE2 that mediates anorexia is unlikely. Also, the idea that there are compensatory mechanisms for deleting one EPreceptor is not probable, since deletion of one EP-receptor had been shown to inhibit fever [154] or conditioned place aversion [103]. 


\section{RESULTS \& DISCUSSION}

Involvement of PGE2 in peripherally evoked anorexia is strain dependent

Given this background and previous results, we turned the focus on the model itself. The original results showing that KO of mPGES-1 prevented mice from anorexia after IL-1 $\beta$ were from studies carried out in mice of the DBA/1-strain, while the experiments on EPreceptor KO were carried out in mice of the $\mathrm{C} 57 \mathrm{BL} / 6$-strain. Hence, we back-crossed the mPGES-1 KO mice to the $\mathrm{C} 57 \mathrm{BL} / 6$ strain and performed side-by side experiments where mPGES-1 KOs from both strains were tested at the same time. In the DBA/1strain, we reproduced the data from our own laboratory [144], showing that mPGES-1 KO strongly attenuates IL-1 $\beta$-induced anorexia. However, in the $\mathrm{C} 57 \mathrm{BL} / 6$-strain, mPGES-1 KO did not prevent mice from anorexia after peripheral administration of IL$1 \beta$. The involvement of PGE2 in mediating IL-1 $\beta$-induced anorexia was thereby shown to be strain dependent, and to involve different pathways in the two strains tested. Worth emphasizing is that KO of mPGES- 1 in the DBA/1 strain attenuated the anorexigenic response to about a half that of wild-type, suggesting that there are also additional anorexigenic signals arising from mediators other than PGE2 in this strain. This is also supported by the finding that mPGES-1 KO mice (DBA/1) display intact anorexia after peripheral LPS administration [144]. Treatment with a specific COX-2 inhibitor normalized the food intake in $\mathrm{C}_{57} \mathrm{BL} / 6$-mice after IL-1 $\beta$ injection, confirming that peripherally administered immune challenge is dependent on prostanoids in $\mathrm{C}_{57 \mathrm{BL} / 6}$ mice. However, the exact prostanoid or combination of prostanoids that mediates this effect is yet to be determined. 


\section{Paper IV}

\section{Background/Aim}

Recently, it was shown that expression of COX-2 and mPGES-1 in the endothelial cells of the blood-brain barrier are crucial for the fever response, since cell-specific deletion of these enzymes in the endothelial cells of the blood-brain barrier strongly attenuated the fever response [80]. In this study, we wanted to elucidate the cellular origin of the COX-2 expression that mediates anorexia, by cell type-specific gene deletion of COX-2. We also investigated the concordance of the prostaglandin-signaling mechanisms behind conditioned taste aversion and LPS-induced anorexia.

LPS-induced anorexia is COX-2 dependent and is mediated by pathways distinct from that mediating fever

In this study we showed that a COX-2 specific inhibitor as well deletion of the gene encoding COX-2 prevented anorexia in mice. This was specific for COX-2, since mice treated with a specific inhibitor of COX-1 or deletion of the COX-1 gene displayed anorexia that corresponded to un-treated or WT-controls that were given LPS. We thereafter immune challenged mice with specific deletions of COX-2 in neural-, myeloid- or brain endothelial cells, and showed that mice lacking COX-2 expression in the brain endothelial cells had attenuated fever, but intact anorexia. This is in line with results showing that mice lacking TAK-1 in the brain endothelium have attenuated fever, but intact anorexia [78], and the finding that fever [69] but not anorexia [144] is dependent on mPGES-1. Taken together, our results further support the hypothesis that fever and anorexia are mediated by distinct pathways. 


\section{RESULTS \& DISCUSSION}

Mice lacking COX-2 expression in myeloid cells or neural cells displayed both anorexia and fever to the same extent as their WT littermates. In paper II we show that activation of myeloid cells are involved in LPS-induced anorexia, since deleting MyD88 in myeloid cells largely inhibits LPS-induced anorexia. This does not necessary imply that these cells express COX-2 critical for anorexia. By including brain endothelial cells and neurons/glial cells, the main sources of induced COX-2 expression are covered, but none of them seems to be solitarily involved. The conclusion we draw is that there might be redundant signaling pathway for prostaglandins mediating anorexia, since the response is dependent on COX-2 signaling, but not from a distinct cell population known to express COX-2. It could be that COX-2 signaling network is plastic, and if there is loss of function in one system, another cell population will compensate for this.

\section{Conditioned taste aversion is prostaglandin independent}

In this study, we developed a protocol for conditioned taste aversion in which we conditioned the taste from saccharin to low-dose LPS. Recently, Fritz et al. demonstrated the pathway of inflammation-induced conditioned place aversion, using the same low dose of LPS as used in this work. In that study, we could show that conditioned place aversion induced by LPS is dependent on PGE2 production by COX-1 and subsequent binding of PGE2 to EP1 receptors on dopamine D1 receptor expressing neurons in the striatum [103]. In this study, pre-treatment of specific inhibitors for COX-1 or COX-2 did not prevent mice from acquiring conditioned taste aversion towards saccharin when pairing saccharin with LPS, thus this pathway is prostaglandin independent. This makes the pathways underlying conditioned taste aversion distinct from those of fever, anorexia and place aversion, since they all have been shown to be dependent on prostaglandin-signaling in various ways. 


\section{CONCLUDING REMARKS}

Anorexia is a salient feature of the acute phase response, as well as a ubiquitous manifestation of severe, chronic diseases. The focus of this thesis was to investigate the role of inflammatory mediators in evoking anorexia. Specifically, we have investigated the role of prostaglandin E2 and the prostaglandin synthesizing enzymes COX-1, COX-2 and mPGES-1. We have been able to confirm that LPS-induced anorexia is prostaglandin dependent, since inhibition of COX-2 completely abolished the anorexigenic response (paper IV), but we could not determine the key cell-type mediating anorexia after administration of LPS. However, we showed that anorexia, fever and taste aversion are mediated by distinct pathways, since fever is highly dependent on COX-2 expression in brain endothelial cells, whereas anorexia is not, and taste aversion seems to be prostaglandin independent. In paper II, we confirmed that expression of MyD88 is essential for inflammatory anorexia. Furthermore, we could show that hematopoietic- and myeloid cells are crucial for LPS-induced anorexia. Inflammation-induced anorexia and cancer-induced anorexia are both dependent on prostaglandins, since un-specific inhibition of COX-enzymes abolishes anorexia in both tumor-bearing mice and after LPS administration (paper I, III, and IV). Specifically, COX-2 is the crucial isoenzyme in inflammation-induced anorexia (paper IV), whereas COX-1 plays an important role in the initial phases of cancer-induced anorexia (paper I) suggesting that the pathways for these two aspects of anorexia are distinct. Furthermore, we also showed that PGE2 is not as crucial for inflammation-induced or cancer-induced anorexia as previously thought, and that the discrepancy between our findings and findings reported in these earlier studies probably is due to the use of different strains of mice (paper III).

The pathways by which inflammatory signals, especially prostaglandins, reach the brain have been in the spotlight of this thesis. This does not, however, exclude the involvement of other mediators. In close proximity to the feeding regulatory centers in the brain are the circumventricular organs (CVOs), which may respond to inflammation 


\section{CONCLUDING REMARKS}

since TLR4 is strongly up-regulated in the sensory CVOs in mice [197, 198] and astrocyte-tanycytes in these regions have been shown to be responsive to LPS [46, 197]. Another possible candidate with extensive capacity for regulating feeding is the vagus nerve. Thus, the involvement of the vagus innervation in regulating feeding during inflammatory conditions has been examined but the results are contradictory. This is mostly due to the effect vagotomy has on physiological food intake, since vagotomy largely affects the motility and emptying of the gastrointestinal tract, subsequently affecting release of hormones that will activate or inhibit food regulatory circuits in the hypothalamus and in the brain stem. It is thereby difficult to study the effects of vagotomy in regard to food intake regulation.

Inflammation may act on cell types whose involvement in inflammatory anorexia has not been covered in this thesis. Adipocytes have been shown to be responsive to inflammation [199] and their expression of leptin and leptin's role in food intake regulation during inflammatory states should not be overlooked. Although these cells were not studied here, the role of adipocytes in inflammatory anorexia is certainly a topic that deserves attention in the future.

Another not so well studied area is the processing of prostaglandinergic signaling by higher levels in the brain. How does general prostaglandinergic load affect motivation to eat? In a recent study, we showed that PGE2 modulates dopaminergic signaling in brain areas highly active during motivation and decision-making [103]. It might be that similar events are involved during feeding regulation. Feeding regulatory centers are both innervated by and have projections to several parts of the brain involved in higher functions [17] and it is not far-fetched to propose that feeding regulatory centers in hypothalamus are influenced by higher areas in the brain that are activated by a general prostaglandin load in the brain. 
As a reflection on the results presented in this thesis as well as other projects that lie outside the range of this thesis, anorexia is very difficult to prevent through inhibition of a single pathway. The ability to develop anorexia is likely plastic and extremely important from an evolutionary perspective. This is probably the reason why pathways for anorexia seem to be redundant, in contrast to those of fever and malaise, for which the pathways are very exclusive, since manipulation of solitary signaling cascades to a large extent inhibits the latter responses [69, 80, 103].

Inbred mouse strains were used in all studies of this thesis. In paper III, we showed that the involvement of PGE2 differed between mouse strains, which of course raised the question of how good animal models are in mimicking processes in humans. Thus, we use inbred mice and solitary PAMPs or even just a single cytokine to mimic diseaselike states. This is very far from the physiological processes underlying diseases in humans and expectations must be adapted accordingly. Nonetheless, systematic studies of isolated model systems both in vitro and in vivo provide a natural starting point in the quest for the mechanisms that also underlie anorexia in humans, and most likely provide insight into what might be happening during diseases also in humans.

In summary, although not defining one solitary mechanism of anorexia, the findings presented in this thesis further stress the importance of prostaglandin synthesis to the development of anorexia. Since inhibitors of prostaglandin synthesis (ASA, NSAIDS etc.) are universally available, it is legitimate to ask if there is a need for more detailed insights into the prostaglandinergic twists and turns of anorexia. While use of NSAIDs is efficient, chronic treatment with NSAIDs comes with a wide range of side-effects including kidney- and cardiac problems, as well as ulceration of the gastrointestinal tract (see [200]). These effects are mainly caused by off target-effects of NSAIDs, i.e. they will inhibit prostaglandin synthesis in all tissues where prostaglandins are synthesized and not only where prostaglandins elicit anorexia. This point to the need for the development of more specific treatments and the development of such treatments will have to rest on a more detailed insight into the signaling pathways involved in anorexia. 


\section{ACKNOWLEDGEMENTS}

The work behind this thesis is not a one-man-work. There are a lot of people that have made this possible and here I would like to acknowledge you:

Associate professor David Engblom, my main supervisor. You are the smartest person I know and every time I come and ask you something I always learn how to look at things in new perspectives. Thank you for taking me into your group and always being supportive and enthusiastic, despite all the negative results that have been haunting me. Although I must admit to stop believing that all experiments would be a "SUCCÉ" after approximately three years.

Professor Anders Blomqvist, my co-supervisor. You have taught me the value of being stringent and to always questioning my results by being the "devil's advocate" when I present data to you. I have learned so much from it, and I always knew that I had your support if I needed it. Thank you for great scientific discussions and supervision during these years.

Daniel Wilhelms. I have never met a person with such intellect as yours and I am fortunate to have had you as my closest college and scientific discussion partner. Our shared interest in strange YouTube-clips and people with JET engines mounted on bikes and wheel-chairs have given my time in the lab a gilt edge and I cannot stress enough how much I appreciate you as a college and friend. Thanks for everything!

Sofie Sundberg, for all the pep-talks, support and discussions during late hours at the office, at the playground or during long hours of histology-examinations. You rock and I am really happy to have had the opportunity to get to know you! Also thank you for helping me with the creation of the cover for this book!

Nina Ottosson, for being such a wonderful friend and supporter since my first day in the lab, and for always cheering me up with that catching laugh of yours! :) You are the ray of sun at floor 11 !

Johan Ruud, my anorexia-mentor and role-model, for teaching me the value of being precise (three decimals to be exact) and for sharing your fantastic knowledge about neuroscience. It has been really empty here during late nights since you went to Germany, and I really miss having yours and Daniel's company during the unholy hours of anorexia experiments. 
Kiseko Shionoya, for sharing your extensive knowledge about animal behavior, and for always greeting me with a smile and a lot of enthusiasm when I come to ask you something. I really enjoy our discussions and your fantastic sense of humor.

Maarit Jaarola for impeccable technical assistance and for always having amusing stories to share.

To people in the Engblom lab: Anna Klawonn and Michael Fritz for nice collaborations and discussions, Elahe Mirrasekhian for always offering to help and for being a good friend, Joanna “Aisa" Zajdel for always being helpful, your great sense of humor and interesting discussions, Andrea Stojakovic and Anand Kumar Singh for nice scientific discussions. Also thank you to all student that have come to the Engblom lab during the years, especially Fredrik A, Annelie, Christine, Hulda, Maria, Michaela, Leo, Philip, Isabell, Redoy and Emma.

To people in the Blomqvist lab: Anna Eskilsson for always being cheerful and for being my fellow "pop-snöre" and to Unn Örtegren Kugelberg for technical assistance and for contributing to the nice environment at floor 11. Thank you also to former members of the group and associated groups, especially Camilla, Namik, Ana-Maria and Takashi for discussions and being supportive.

Other people at floor 11 during the years: Johan Brask and Sara Liin for interesting and fun discussions both inside and outside the coffee-room, Fredrik Elinder for interesting discussions about science and graduate school, Jakob Renhorn, Malin Silverå Ejneby, Urban Karlsson, Luca Conti, Ulrika Englund, Björn Granseth, Sarah Lindström, Gonzalo Manuel Sanches and Ayman Osman for always being friendly and helpful, and for many laughs around the coffee-table.

Simin Mosheni for being such a nice person that you are and for great support during my time at floor 11, especially when it comes to teaching.

Milen Kirilov for trying to teach me the art of cloning.

All the staff at the animal facility: You have always been so helpful and trying your best to satisfy my never-ending needs for enormous test-groups that have to be caged individually. A special thanks to Anders, Andreas, Paulina, Albin, Linda, Cissi and Nettan.

Larry Lundgren for proofreading this thesis. 
Johanna Karlsson, Simon Jönsson and Thommie Karlsson for being great friends since the MedBi-years.

Pernilla Eliasson for your friendship and pep-talks. I really enjoy our fikas, lunches and dinners. Our motto should be När du vill vara dig själv för en stund (although I think that we have not shared a Norrlands yet).

Anna Fahlgren for introducing me to the world of research and for being a great mentor and role-model.

Susanne Andersson for our talks about "the good old days" at MedBi. It's always nice with a stroll down the memory lane (or in some cases lack of memory...).

My friends on the outside: Emelie Karlsson for being my partner in crime for a lot of years now. You and your family have meant so much for me during the years and I am fortunate to have a friend as you. Josefine Ekström, Hanna Thunberg and Helena Gustavsson for always being supportive, cheering me up and wonderful and funny to be around!

Farfar Bertil för ditt stöd och för att du alltid funnits där för mig och mina syskon under vår uppväxt.

Min lillebror Johannes för din förmåga att se det bästa hos alla och för många intressanta diskussioner om det mesta.

Min syster Sofia, min svåger Adam och min systerdotter Selma för att ni alltid finns där.

Mamma och Pappa. Inget jag skriver här kan illusterar den tacksamhet som jag känner gentemot er så det får bli ett enkelt: Tack för ert ovillkorliga stöd i allt!

Erik och Nils. För att ni varje dag påminner mig om vad som är viktigt på riktigt och för att ni alltid får mig att känna mig uppskattad och älskad. Ni ger mitt liv mening och jag påminner mig själv varje dag hur lyckligt lottad jag är som har er i mitt liv.

I've gained some recognition but I lost my appetite

Bob Dylan 


\section{LIST OF REFERENCES}

1. Ritter, R.C., Gastrointestinal mechanisms of satiation for food. Physiol Behav, 2004. 81(2): p. 249-73.

2. Gibbs, J., R.C. Young, and G.P. Smith, Cholecystokinin elicits satiety in rats with open gastric fistulas. Nature, 1973. 245(5424): p. 323-5.

3. Corp, E.S., et al., Characterization of type A and type B CCK receptor binding sites in rat vagus nerve. Brain Res, 1993. 623(1): p. 161-6.

4. Turton, M.D., et al., A role for glucagon-like peptide-1 in the central regulation of feeding. Nature, 1996. 379(6560): p. 69-72.

5. Cummings, D.E. and J. Overduin, Gastrointestinal regulation of food intake. J Clin Invest, 2007. 117(1): p. 13-23.

6. Williams, K.W. and J.K. Elmquist, From neuroanatomy to behavior: central integration of peripheral signals regulating feeding behavior. Nat Neurosci, 2012. 15(10): p. 1350-5.

7. Merchenthaler, I., M. Lane, and P. Shughrue, Distribution of pre-pro-glucagon and glucagon-like peptide-1 receptor messenger RNAs in the rat central nervous system. $\mathrm{J}$ Comp Neurol, 1999. 403(2): p. 261-80.

8. Schwartz, M.W., Central nervous system regulation of food intake. Obesity (Silver Spring), 2006. 14 Suppl 1: p. 1S-8S.

9. Zhang, Y., et al., Positional cloning of the mouse obese gene and its human homologue. Nature, 1994. 372(6505): p. 425-32.

10. Considine, R.V., et al., Serum immunoreactive-leptin concentrations in normal-weight and obese humans. N Engl J Med, 1996. 334(5): p. 292-5.

11. Lee, G.H., et al., Abnormal splicing of the leptin receptor in diabetic mice. Nature, 1996. 379(6566): p. 632-5.

12. Chen, H., et al., Evidence that the diabetes gene encodes the leptin receptor: identification of a mutation in the leptin receptor gene in db/db mice. Cell, 1996. 84(3): p. 491-5.

13. Tartaglia, L.A., et al., Identification and expression cloning of a leptin receptor, OB-R. Cell, 1995. 83(7): p. 1263-71.

14. Valassi, E., M. Scacchi, and F. Cavagnini, Neuroendocrine control of food intake. Nutr Metab Cardiovasc Dis, 2008. 18(2): p. 158-68.

15. Cummings, D.E., et al., A preprandial rise in plasma ghrelin levels suggests a role in meal initiation in humans. Diabetes, 2001. 50(8): p. 1714-9.

16. Gualillo, O., et al., Effect of food restriction on ghrelin in normal-cycling female rats and in pregnancy. Obes Res, 2002. 10(7): p. 682-7.

17. Broberger, C., Brain regulation of food intake and appetite: molecules and networks. $\mathrm{J}$ Intern Med, 2005. 258(4): p. 301-27.

18. Mizuno, Y. and Y. Oomura, Glucose responding neurons in the nucleus tractus solitarius of the rat: in vitro study. Brain Res, 1984. 307(1-2): p. 109-16.

19. Faulconbridge, L.F., et al., Hyperphagic effects of brainstem ghrelin administration. Diabetes, 2003. 52(9): p. 2260-5.

20. Grill, H.J., et al., Brainstem application of melanocortin receptor ligands produces longlasting effects on feeding and body weight. J Neurosci, 1998. 18(23): p. 10128-35. 
21. Stanley, B.G. and W.J. Thomas, Feeding responses to perifornical hypothalamic injection of neuropeptide $Y$ in relation to circadian rhythms of eating behavior. Peptides, 1993. 14(3): p. 475-81.

22. Ollmann, M.M., et al., Antagonism of central melanocortin receptors in vitro and in vivo by agouti-related protein. Science, 1997. 278(5335): p. 135-8.

23. Schwartz, M.W., et al., Central nervous system control of food intake. Nature, 2000. 404(6778): p. 661-71.

24. Huszar, D., et al., Targeted disruption of the melanocortin-4 receptor results in obesity in mice. Cell, 1997. 88(1): p. 131-41.

25. Fan, W., et al., Role of melanocortinergic neurons in feeding and the agouti obesity syndrome. Nature, 1997. 385(6612): p. 165-8.

26. Balthasar, N., et al., Divergence of melanocortin pathways in the control of food intake and energy expenditure. Cell, 2005. 123(3): p. 493-505.

27. Marsh, D.J., et al., Response of melanocortin-4 receptor-deficient mice to anorectic and orexigenic peptides. Nat Genet, 1999. 21(1): p. 119-22.

28. Thim, L., et al., CART, a new anorectic peptide. Int J Biochem Cell Biol, 1998. 30(12): p. 1281-4.

29. Kristensen, P., et al., Hypothalamic CART is a new anorectic peptide regulated by leptin. Nature, 1998. 393(6680): p. 72-6.

30. Aja, S., et al., Intracerebroventricular CART peptide reduces food intake and alters motor behavior at a hindbrain site. Am J Physiol Regul Integr Comp Physiol, 2001. 281(6): p. R1862-7.

31. Cowley, M.A., et al., Leptin activates anorexigenic POMC neurons through a neural network in the arcuate nucleus. Nature, 2001. 411(6836): p. 480-4.

32. Stephens, T.W., et al., The role of neuropeptide $Y$ in the antiobesity action of the obese gene product. Nature, 1995. 377(6549): p. 530-2.

33. van der Kooy, D., et al., The organization of projections from the cortex, amygdala, and hypothalamus to the nucleus of the solitary tract in rat. J Comp Neurol, 1984. 224(1): p. $1-24$.

34. Schumann, R.R., et al., Structure and function of lipopolysaccharide binding protein. Science, 1990. 249(4975): p. 1429-31.

35. Wang, C., et al., TAK1 is a ubiquitin-dependent kinase of MKK and IKK. Nature, 2001. 412(6844): p. 346-51.

36. Banks, W.A. and A.J. Kastin, Passage of peptides across the blood-brain barrier: pathophysiological perspectives. Life Sci, 1996. 59(23): p. 1923-43.

37. Banks, W.A., A.J. Kastin, and E.G. Gutierrez, Penetration of interleukin-6 across the murine blood-brain barrier. Neurosci Lett, 1994. 179(1-2): p. 53-6.

38. Banks, W.A., et al., Human interleukin (IL) 1 alpha, murine IL-1 alpha and murine IL-1 beta are transported from blood to brain in the mouse by a shared saturable mechanism. J Pharmacol Exp Ther, 1991. 259(3): p. 988-96.

39. Gutierrez, E.G., W.A. Banks, and A.J. Kastin, Murine tumor necrosis factor alpha is transported from blood to brain in the mouse. J Neuroimmunol, 1993. 47(2): p. 169-76.

40. Banks, W.A., A.J. Kastin, and R.D. Broadwell, Passage of cytokines across the bloodbrain barrier. Neuroimmunomodulation, 1995. 2(4): p. 241-8.

41. Lee, H.Y., M.B. Whiteside, and M. Herkenham, Area postrema removal abolishes stimulatory effects of intravenous interleukin-1beta on hypothalamic-pituitary-adrenal 
axis activity and c-fos mRNA in the hypothalamic paraventricular nucleus. Brain Res Bull, 1998. 46(6): p. 495-503.

42. Ericsson, A., C. Arias, and P.E. Sawchenko, Evidence for an intramedullary prostaglandin-dependent mechanism in the activation of stress-related neuroendocrine circuitry by intravenous interleukin-1. J Neurosci, 1997. 17(18): p. 7166-79.

43. Takahashi, Y., et al., Circumventricular organs and fever. Vol. 273. 1997. R1690-R1695.

44. Stitt, J.T., Evidence for the involvement of the organum vasculosum laminae terminalis in the febrile response of rabbits and rats. J Physiol, 1985. 368: p. 501-11.

45. Peruzzo, B., et al., A second look at the barriers of the medial basal hypothalamus. Exp Brain Res, 2000. 132(1): p. 10-26.

46. Gautron, L., et al., Spatiotemporal analysis of signal transducer and activator of transcription 3 activation in rat brain astrocytes and pituitary following peripheral immune challenge. Neuroscience, 2002. 112(3): p. 717-29.

47. Gelman, A.E., et al., Toll-like receptor ligands directly promote activated CD4+ T cell survival. J Immunol, 2004. 172(10): p. 6065-73.

48. Lacroix, S., D. Feinstein, and S. Rivest, The bacterial endotoxin lipopolysaccharide has the ability to target the brain in upregulating its membrane CD14 receptor within specific cellular populations. Brain Pathol, 1998. 8(4): p. 625-40.

49. Laflamme, N., S. Lacroix, and S. Rivest, An essential role of interleukin-1beta in mediating NF-kappaB activity and COX-2 transcription in cells of the blood-brain barrier in response to a systemic and localized inflammation but not during endotoxemia. J Neurosci, 1999. 19(24): p. 10923-30.

50. Vallieres, L. and S. Rivest, Regulation of the genes encoding interleukin-6, its receptor, and gp130 in the rat brain in response to the immune activator lipopolysaccharide and the proinflammatory cytokine interleukin-1beta. J Neurochem, 1997. 69(4): p. 1668-83.

51. Ericsson, A., et al., Type 1 interleukin-1 receptor in the rat brain: distribution, regulation, and relationship to sites of IL-1-induced cellular activation. J Comp Neurol, 1995. 361(4): p. 681-98.

52. Silverman, A.J., D.L. Hoffman, and E.A. Zimmerman, The descending afferent connections of the paraventricular nucleus of the hypothalamus (PVN). Brain Res Bull, 1981. 6(1): p. 47-61.

53. Larsen, P.J. and J.D. Mikkelsen, Functional identification of central afferent projections conveying information of acute "stress" to the hypothalamic paraventricular nucleus. $\mathrm{J}$ Neurosci, 1995. 15(4): p. 2609-27.

54. Ciriello, J. and M.B. Gutman, Functional identification of central pressor pathways originating in the subfornical organ. Can J Physiol Pharmacol, 1991. 69(7): p. 1035-45.

55. Hosoi, T., et al., Novel pathway for LPS-induced afferent vagus nerve activation: possible role of nodose ganglion. Auton Neurosci, 2005. 120(1-2): p. 104-7.

56. Ek, M., et al., Activation of vagal afferents after intravenous injection of interleukin1beta: role of endogenous prostaglandins. J Neurosci, 1998. 18(22): p. 9471-9.

57. Goehler, L.E., et al., Vagal paraganglia bind biotinylated interleukin-1 receptor antagonist: a possible mechanism for immune-to-brain communication. Brain Res Bull, 1997. 43(3): p. 357-64.

58. Wan, W., et al., Differential induction of c-Fos immunoreactivity in hypothalamus and brain stem nuclei following central and peripheral administration of endotoxin. Brain Res Bull, 1993. 32(6): p. 581-7. 
59. Wan, W., et al., Neural and biochemical mediators of endotoxin and stress-induced c-fos expression in the rat brain. Brain Res Bull, 1994. 34(1): p. 7-14.

60. Bret-Dibat, J.L., et al., Lipopolysaccharide and interleukin-1 depress food-motivated behavior in mice by a vagal-mediated mechanism. Brain Behav Immun, 1995. 9(3): p. 242-6.

61. Bluthe, R.M., et al., Vagotomy attenuates behavioural effects of interleukin-1 injected peripherally but not centrally. Neuroreport, 1996. 7(9): p. 1485-8.

62. Porter, M.H., et al., Vagal and splanchnic afferents are not necessary for the anorexia produced by peripheral IL-1beta, LPS, and MDP. Am J Physiol, 1998. 275(2 Pt 2): p. R384-9.

63. Matsumura, K., et al., Cyclooxygenase in the vagal afferents: is it involved in the brain prostaglandin response evoked by lipopolysaccharide? Auton Neurosci, 2000. 85(1-3): p. 88-92.

64. Van Dam, A.M., et al., Interleukin-1 receptors on rat brain endothelial cells: a role in neuroimmune interaction? FASEB J, 1996. 10(2): p. 351-6.

65. Quan, N., et al., Induction of inhibitory factor kappaBalpha mRNA in the central nervous system after peripheral lipopolysaccharide administration: an in situ hybridization histochemistry study in the rat. Proc Natl Acad Sci U S A, 1997. 94(20): p. 10985-90.

66. Konsman, J.P., et al., Rat brain vascular distribution of interleukin-1 type-1 receptor immunoreactivity: relationship to patterns of inducible cyclooxygenase expression by peripheral inflammatory stimuli. J Comp Neurol, 2004. 472(1): p. 113-29.

67. Ek, M., et al., Inflammatory response: pathway across the blood-brain barrier. Nature, 2001. 410(6827): p. 430-1.

68. Li, S., et al., The febrile response to lipopolysaccharide is blocked in cyclooxygenase-2(/-), but not in cyclooxygenase-1(-/-) mice. Brain Res, 1999. 825(1-2): p. 86-94.

69. Engblom, D., et al., Microsomal prostaglandin E synthase-1 is the central switch during immune-induced pyresis. Nat Neurosci, 2003. 6(11): p. 1137-8.

70. Engblom, D., et al., Prostaglandins as inflammatory messengers across the blood-brain barrier. J Mol Med (Berl), 2002. 80(1): p. 5-15.

71. Engstrom, L., et al., Lipopolysaccharide-Induced Fever Depends on Prostaglandin E2 Production Specifically in Brain Endothelial Cells. Endocrinology, 2012. 153(10): p. 4849-4861.

72. Yamagata, K., et al., Coexpression of microsomal-type prostaglandin E synthase with cyclooxygenase-2 in brain endothelial cells of rats during endotoxin-induced fever. $\mathrm{J}$ Neurosci, 2001. 21(8): p. 2669-77.

73. Matsumura, K., et al., Brain endothelial cells express cyclooxygenase-2 during lipopolysaccharide-induced fever: light and electron microscopic immunocytochemical studies. J Neurosci, 1998. 18(16): p. 6279-89.

74. Engblom, D., et al., Induction of microsomal prostaglandin E synthase in the rat brain endothelium and parenchyma in adjuvant-induced arthritis. J Comp Neurol, 2002. 452(3): p. 205-14.

75. Cao, C., et al., Endothelial cells of the rat brain vasculature express cyclooxygenase-2 $m R N A$ in response to systemic interleukin-1 beta: a possible site of prostaglandin synthesis responsible for fever. Brain Res, 1996. 733(2): p. 263-72. 


\section{LIST OF REFERENCES}

76. Schiltz, J.C. and P.E. Sawchenko, Distinct brain vascular cell types manifest inducible cyclooxygenase expression as a function of the strength and nature of immune insults. $\mathrm{J}$ Neurosci, 2002. 22(13): p. 5606-5618.

77. Elmquist, J.K., et al., Intravenous lipopolysaccharide induces cyclooxygenase 2-like immunoreactivity in rat brain perivascular microglia and meningeal macrophages. $\mathrm{J}$ Comp Neurol, 1997. 381(2): p. 119-29.

78. Ridder, D.A., et al., TAK1 in brain endothelial cells mediates fever and lethargy. J Exp Med, 2011. 208(13): p. 2615-23.

79. Eskilsson, A., et al., Immune-induced fever is mediated by IL-6 receptors on brain endothelial cells coupled to STAT3-dependent induction of brain endothelial prostaglandin synthesis. J Neurosci, 2014. 34(48): p. 15957-61.

80. Wilhelms, D.B., et al., Deletion of prostaglandin E2 synthesizing enzymes in brain endothelial cells attenuates inflammatory fever. J Neurosci, 2014. 34(35): p. 11684-90.

81. Vane, J.R., Inhibition of prostaglandin synthesis as a mechanism of action for aspirinlike drugs. Nat New Biol, 1971. 231(25): p. 232-5.

82. von Euler, U.S., On the specific vaso-dilating and plain muscle stimulating substances from accessory genital glands in man and certain animals (prostaglandin and vesiglandin). J Physiol, 1936. 88(2): p. 213-34.

83. Kudo, I. and M. Murakami, Phospholipase A2 enzymes. Prostaglandins Other Lipid Mediat, 2002. 68-69: p. 3-58.

84. Merlie, J.P., et al., Isolation and characterization of the complementary DNA for sheep seminal vesicle prostaglandin endoperoxide synthase (cyclooxygenase). J Biol Chem, 1988. 263(8): p. 3550-3.

85. DeWitt, D.L. and W.L. Smith, Primary structure of prostaglandin G/H synthase from sheep vesicular gland determined from the complementary DNA sequence. Proc Natl Acad Sci U S A, 1988. 85(5): p. 1412-6.

86. Kujubu, D.A., et al., TIS10, a phorbol ester tumor promoter-inducible mRNA from Swiss $3 T 3$ cells, encodes a novel prostaglandin synthase/cyclooxygenase homologue. J Biol Chem, 1991. 266(20): p. 12866-72.

87. Xie, W.L., et al., Expression of a mitogen-responsive gene encoding prostaglandin synthase is regulated by mRNA splicing. Proc Natl Acad Sci U S A, 1991. 88(7): p. 26926.

88. Smith, W.L., D.L. DeWitt, and R.M. Garavito, Cyclooxygenases: structural, cellular, and molecular biology. Annu Rev Biochem, 2000. 69: p. 145-82.

89. Vane, J.R., Y.S. Bakhle, and R.M. Botting, Cyclooxygenases 1 and 2. Annu Rev Pharmacol Toxicol, 1998. 38: p. 97-120.

90. Vane, J.R., COX-2 inhibitors: background knowledge for clinical use. Introduction. Inflamm Res, 1998. 47 Suppl 2: p. S77.

91. Kaufmann, W.E., et al., Cyclooxygenases and the central nervous system. Prostaglandins, 1997. 54(3): p. 601-24.

92. Dubois, R.N., et al., Cyclooxygenase in biology and disease. FASEB J, 1998. 12(12): p. 1063-73.

93. Yamagata, K., et al., Expression of a mitogen-inducible cyclooxygenase in brain neurons: regulation by synaptic activity and glucocorticoids. Neuron, 1993. 11(2): p. 371-86.

94. Breder, C.D., D. Dewitt, and R.P. Kraig, Characterization of inducible cyclooxygenase in rat brain. J Comp Neurol, 1995. 355(2): p. 296-315. 
95. Beuckmann, C.T., et al., Identification of mu-class glutathione transferases M2-2 and M3-3 as cytosolic prostaglandin E synthases in the human brain. Neurochem Res, 2000. 25(5): p. 733-8.

96. Jakobsson, P.J., et al., Identification of human prostaglandin E synthase: a microsomal, glutathione-dependent, inducible enzyme, constituting a potential novel drug target. Proc Natl Acad Sci U S A, 1999. 96(13): p. 7220-5.

97. Tanikawa, N., et al., Identification and characterization of a novel type of membraneassociated prostaglandin E synthase. Biochem Biophys Res Commun, 2002. 291(4): p. 884-9.

98. Vasilache, A.M., H. Qian, and A. Blomqvist, Immune challenge by intraperitoneal administration of lipopolysaccharide directs gene expression in distinct blood-brain barrier cells toward enhanced prostaglandin E(2) signaling. Brain Behav Immun, 2015. 48: p. 31-41.

99. Tanioka, T., et al., Molecular identification of cytosolic prostaglandin E2 synthase that is functionally coupled with cyclooxygenase-1 in immediate prostaglandin E2 biosynthesis. J Biol Chem, 2000. 275(42): p. 32775-82.

100. Jakobsson, P.J., et al., Characterization of microsomal, glutathione dependent prostaglandin E synthase. Adv Exp Med Biol, 2002. 507: p. 287-91.

101. Pecchi, E., et al., Involvement of central microsomal prostaglandin E synthase-1 in IL1beta-induced anorexia. Physiol Genomics, 2006. 25(3): p. 485-92.

102. Pecchi, E., et al., mPGES-1 knock-out mice are resistant to cancer-induced anorexia despite the absence of central mPGES-1 up-regulation in wild-type anorexic mice. $\mathrm{J}$ Neuroimmunol, 2008. 199(1-2): p. 104-14.

103. Fritz, M., et al., Prostaglandin-dependent modulation of dopaminergic neurotransmission elicits inflammation-induced aversion in mice. J Clin Invest, 2015.

104. Exton, M.S., Infection-induced anorexia: active host defence strategy. Appetite, 1997. 29(3): p. 369-83.

105. Kyriazakis, I.I., B.J. Tolkamp, and M.R. Hutchings, Towards a functional explanation for the occurrence of anorexia during parasitic infections. Anim Behav, 1998. 56(2): p. 265274.

106. Ganz, T., Iron in innate immunity: starve the invaders. Curr Opin Immunol, 2009. 21(1): p. 63-7.

107. Hart, B.L., Biological basis of the behavior of sick animals. Neurosci Biobehav Rev, 1988. 12(2): p. 123-37.

108. Jones, R.L., et al., Effects of iron chelators and iron overload on Salmonella infection. Nature, 1977. 267(5606): p. 63-5.

109. Murray, M.J. and A.B. Murray, Anorexia of infection as a mechanism of host defense. Am J Clin Nutr, 1979. 32(3): p. 593-6.

110. Wing, E.J. and J.B. Young, Acute starvation protects mice against Listeria monocytogenes. Infect Immun, 1980. 28(3): p. 771-6.

111. Bruera, E., ABC of palliative care. Anorexia, cachexia, and nutrition. BMJ, 1997. 315(7117): p. 1219-22.

112. Nixon, D.W., et al., Protein-calorie undernutrition in hospitalized cancer patients. Am J Med, 1980. 68(5): p. 683-90.

113. DeWys, W., Management of cancer cachexia. Semin Oncol, 1985. 12(4): p. 452-60. 


\section{LIST OF REFERENCES}

114. Katz, A.M. and P.B. Katz, Diseases of the heart in the works of Hippocrates. Br Heart J, 1962. 24: p. 257-64.

115. Tisdale, M.J., Biology of cachexia. J Natl Cancer Inst, 1997. 89(23): p. 1763-73.

116. Fearon, K., et al., Definition and classification of cancer cachexia: an international consensus. Lancet Oncol, 2011. 12(5): p. 489-95.

117. Evans, W.J., et al., Cachexia: a new definition. Clin Nutr, 2008. 27(6): p. 793-9.

118. Moley, J.F., et al., Body cell mass in cancer-bearing and anorexic patients. JPEN J Parenter Enteral Nutr, 1987. 11(3): p. 219-22.

119. Emery, P.W., Cachexia in experimental models. Nutrition, 1999. 15(7-8): p. 600-3.

120. Svaninger, G., C. Drott, and K. Lundholm, Role of insulin in development of cancer cachexia in nongrowing sarcoma-bearing mice: special reference to muscle wasting. $\mathrm{J}$ Natl Cancer Inst, 1987. 78(5): p. 943-50.

121. Svaninger, G., J. Gelin, and K. Lundholm, The cause of death in non-metastasizing sarcoma-bearing mice. A study with relevance for tumor treatment experiments in mice. Eur J Cancer Clin Oncol, 1989. 25(9): p. 1295-302.

122. Bruera, E., Pharmacological treatment of cachexia: any progress? Support Care Cancer, 1998. 6(2): p. 109-13.

123. Downer, S., et al., A double blind placebo controlled trial of medroxyprogesterone acetate (MPA) in cancer cachexia. Br J Cancer, 1993. 67(5): p. 1102-5.

124. Loprinzi, C.L., et al., Body-composition changes in patients who gain weight while receiving megestrol acetate. J Clin Oncol, 1993. 11(1): p. 152-4.

125. Tisdale, M.J., Molecular pathways leading to cancer cachexia. Physiology (Bethesda), 2005. 20: p. 340-8.

126. Oka, M., et al., Relationship between serum levels of interleukin 6, various disease parameters and malnutrition in patients with esophageal squamous cell carcinoma. Cancer Res, 1996. 56(12): p. 2776-80.

127. Hellerstein, M.K., et al., Interleukin-1-induced anorexia in the rat. Influence of prostaglandins. J Clin Invest, 1989. 84(1): p. 228-35.

128. Luheshi, G.N., et al., Leptin actions on food intake and body temperature are mediated by $I L-1$. Proc Natl Acad Sci U S A, 1999. 96(12): p. 7047-52.

129. Saper, C.B., A.A. Romanovsky, and T.E. Scammell, Neural circuitry engaged by prostaglandins during the sickness syndrome. Nat Neurosci, 2012. 15(8): p. 1088-95.

130. Skibicka, K.P., et al., Neural controls of prostaglandin 2 pyrogenic, tachycardic, and anorexic actions are anatomically distributed. Endocrinology, 2011. 152(6): p. 2400-8.

131. Horton, E.W., Actions of Prostaglandins E1, E2 and E3 on the Central Nervous System. Br J Pharmacol Chemother, 1964. 22: p. 189-92.

132. Wang, W., et al., Cytokine and cyclooxygenase-2 protein in brain areas of tumor-bearing mice with prostanoid-related anorexia. Cancer Res, 2001. 61(12): p. 4707-15.

133. Ohinata, K., et al., Activation of prostaglandin E receptor EP4 subtype suppresses food intake in mice. Prostaglandins Other Lipid Mediat, 2006. 81(1-2): p. 31-6.

134. Levine, A.S. and J.E. Morley, The effect of prostaglandins (PGE2 and PGF2 alpha) on food intake in rats. Pharmacol Biochem Behav, 1981. 15(5): p. 735-8.

135. Dunn, A.J. and A.H. Swiergiel, The role of cyclooxygenases in endotoxin- and interleukin-1-induced hypophagia. Brain Behav Immun, 2000. 14(3): p. 141-52. 
136. Swiergiel, A.H., G.N. Smagin, and A.J. Dunn, Influenza virus infection of mice induces anorexia: comparison with endotoxin and interleukin-1 and the effects of indomethacin. Pharmacol Biochem Behav, 1997. 57(1-2): p. 389-96.

137. McCarthy, H.D., S. Dryden, and G. Williams, Interleukin-1 beta-induced anorexia and pyrexia in rat: relationship to hypothalamic neuropeptide Y. Am J Physiol, 1995. 269(5 Pt 1): p. E852-7.

138. Johnson, R.W. and E. von Borell, Lipopolysaccharide-induced sickness behavior in pigs is inhibited by pretreatment with indomethacin. J Anim Sci, 1994. 72(2): p. 309-14.

139. McHugh, K.J., et al., On the suppression of food intake in experimental models of colitis in the rat. Am J Physiol, 1993. 264(5 Pt 2): p. R871-6.

140. Langhans, W., R. Harlacher, and E. Scharrer, Verapamil and indomethacin attenuate endotoxin-induced anorexia. Physiol Behav, 1989. 46(3): p. 535-9.

141. Langhans, W., et al., Comparison of the effects of bacterial lipopolysaccharide and muramyl dipeptide on food intake. Physiol Behav, 1990. 47(5): p. 805-13.

142. Johnson, P.M., et al., COX-2 inhibition attenuates anorexia during systemic inflammation without impairing cytokine production. Am J Physiol Endocrinol Metab, 2002. 282(3): p. E650-6.

143. Lugarini, F., et al., A role for cyclooxygenase-2 in lipopolysaccharide-induced anorexia in rats. Am J Physiol Regul Integr Comp Physiol, 2002. 283(4): p. R862-8.

144. Elander, L., et al., IL-1beta and LPS induce anorexia by distinct mechanisms differentially dependent on microsomal prostaglandin E synthase-1. Am J Physiol Regul Integr Comp Physiol, 2007. 292(1): p. R258-67.

145. Kopf, B.S., et al., Evidence that PGE2 in the dorsal and median raphe nuclei is involved in LPS-induced anorexia in rats. Pharmacol Biochem Behav, 2011. 99(3): p. 437-43.

146. Dunn, A.J., et al., Reduced ingestion of sweetened milk induced by interleukin-1 and lipopolysaccharide is associated with induction of cyclooxygenase-2 in brain endothelia. Neuroimmunomodulation, 2006. 13(2): p. 96-104.

147. Asarian, L. and W. Langhans, A new look on brain mechanisms of acute illness anorexia. Physiol Behav, 2010. 100(5): p. 464-71.

148. Oka, T., et al., Relationship of EP(1-4) prostaglandin receptors with rat hypothalamic cell groups involved in lipopolysaccharide fever responses. J Comp Neurol, 2000. 428(1): p. 20-32.

149. Ek, M., et al., Distribution of the EP3 prostaglandin E(2) receptor subtype in the rat brain: relationship to sites of interleukin-1-induced cellular responsiveness. J Comp Neurol, 2000. 428(1): p. 5-20.

150. Batshake, B., C. Nilsson, and J. Sundelin, Molecular characterization of the mouse prostanoid EP1 receptor gene. Eur J Biochem, 1995. 231(3): p. 809-14.

151. Zhang, J. and S. Rivest, Distribution, regulation and colocalization of the genes encoding the EP2- and EP4-PGE2 receptors in the rat brain and neuronal responses to systemic inflammation. Eur J Neurosci, 1999. 11(8): p. 2651-68.

152. Matsuoka, Y., et al., Prostaglandin E receptor EP1 controls impulsive behavior under stress. Proc Natl Acad Sci U S A, 2005. 102(44): p. 16066-71.

153. Lazarus, M., et al., EP3 prostaglandin receptors in the median preoptic nucleus are critical for fever responses. Nat Neurosci, 2007.

154. Ushikubi, F., et al., Impaired febrile response in mice lacking the prostaglandin E receptor subtype EP3. Nature, 1998. 395(6699): p. 281-4. 


\section{LIST OF REFERENCES}

155. Oka, T., et al., Characteristics of thermoregulatory and febrile responses in mice deficient in prostaglandin EP1 and EP3 receptors. J Physiol, 2003. 551(Pt 3): p. 945-54.

156. Parrott, R.F. and S.V. Vellucci, Effects of centrally administered prostaglandin EP receptor agonists on febrile and adrenocortical responses in the prepubertal pig. Brain Res Bull, 1996. 41(2): p. 97-103.

157. Reinold, H., et al., Spinal inflammatory hyperalgesia is mediated by prostaglandin E receptors of the EP2 subtype. J Clin Invest, 2005. 115(3): p. 673-9.

158. Laflamme, N. and S. Rivest, Effects of systemic immunogenic insults and circulating proinflammatory cytokines on the transcription of the inhibitory factor kappaB alpha within specific cellular populations of the rat brain. J Neurochem, 1999. 73(1): p. 30921.

159. Parnet, P., et al., Expression and regulation of interleukin-1 receptors in the brain. Role in cytokines-induced sickness behavior. J Neuroimmunol, 2002. 125(1-2): p. 5-14.

160. Licinio, J. and M.L. Wong, Pathways and mechanisms for cytokine signaling of the central nervous system. J Clin Invest, 1997. 100(12): p. 2941-7.

161. Konsman, J.P. and R. Dantzer, How the immune and nervous systems interact during disease-associated anorexia. Nutrition, 2001. 17(7-8): p. 664-8.

162. Waelput, W., et al., A role for leptin in the systemic inflammatory response syndrome (SIRS) and in immune response. Curr Drug Targets Inflamm Allergy, 2002. 1(3): p. $277-$ 89.

163. Grunfeld, C., et al., Endotoxin and cytokines induce expression of leptin, the ob gene product, in hamsters. J Clin Invest, 1996. 97(9): p. 2152-7.

164. Hosoi, T., Y. Okuma, and Y. Nomura, Leptin regulates interleukin-1beta expression in the brain via the STAT3-independent mechanisms. Brain Res, 2002. 949(1-2): p. 139-46.

165. Steiner, A.A. and A.A. Romanovsky, Leptin: at the crossroads of energy balance and systemic inflammation. Prog Lipid Res, 2007. 46(2): p. 89-107.

166. Marks, D.L., N. Ling, and R.D. Cone, Role of the central melanocortin system in cachexia. Cancer Res, 2001. 61(4): p. 1432-8.

167. Wisse, B.E., K. Ogimoto, and M.W. Schwartz, Role of hypothalamic interleukin-1beta (IL-1beta) in regulation of energy homeostasis by melanocortins. Peptides, 2006. 27(2): p. 265-73.

168. Huang, Q.H., V.J. Hruby, and J.B. Tatro, Role of central melanocortins in endotoxininduced anorexia. Am J Physiol, 1999. 276(3 Pt 2): p. R864-71.

169. Paues, J., L. Mackerlova, and A. Blomqvist, Expression of melanocortin-4 receptor by rat parabrachial neurons responsive to immune and aversive stimuli. Neuroscience, 2006. 141(1): p. 287-97.

170. Garfield, A.S., et al., A neural basis for melanocortin-4 receptor-regulated appetite. Nat Neurosci, 2015. 18(6): p. 863-71.

171. Lawrence, C.B. and N.J. Rothwell, Anorexic but not pyrogenic actions of interleukin-1 are modulated by central melanocortin-3/4 receptors in the rat. J Neuroendocrinol, 2001. 13(6): p. 490-5.

172. Mattes, R.D., et al., Clinical implications of learned food aversions in patients with cancer treated with chemotherapy or radiation therapy. Cancer, 1992. 70(1): p. 192-200.

173. Jacobsen, P.B., et al., Formation of food aversions in cancer patients receiving repeated infusions of chemotherapy. Behav Res Ther, 1993. 31(8): p. 739-48. 
174. Aubert, A. and R. Dantzer, The taste of sickness: lipopolysaccharide-induced finickiness in rats. Physiol Behav, 2005. 84(3): p. 437-44.

175. Vichaya, E.G., S.C. Hunt, and R. Dantzer, Lipopolysaccharide reduces incentive motivation while boosting preference for high reward in mice. Neuropsychopharmacology, 2014. 39(12): p. 2884-90.

176. Carter, M.E., et al., Genetic identification of a neural circuit that suppresses appetite. Nature, 2013. 503(7474): p. 111-4.

177. Carter, M.E., S. Han, and R.D. Palmiter, Parabrachial calcitonin gene-related peptide neurons mediate conditioned taste aversion. J Neurosci, 2015. 35(11): p. 4582-6.

178. Weingarten, S., M. Senn, and W. Langhans, Does a learned taste aversion contribute to the anorectic effect of bacterial lipopolysaccharide? Physiol Behav, 1993. 54(5): p. 9616.

179. Lakso, M., et al., Targeted oncogene activation by site-specific recombination in transgenic mice. Proceedings of the National Academy of Sciences, 1992. 89(14): p. 6232-6236.

180. Gu, H., Y.-R. Zou, and K. Rajewsky, Independent control of immunoglobulin switch recombination at individual switch regions evidenced through Cre- $\langle i>$ loxP $\langle/ i\rangle-$ mediated gene targeting. Cell, 1993. 73(6): p. 1155-1164.

181. Sanchez-Cantu, L., H.N. Rode, and N.V. Christou, Endotoxin tolerance is associated with reduced secretion of tumor necrosis factor. Arch Surg, 1989. 124(12): p. 1432-5; discussion 1435-6.

182. Lundholm, K., et al., A comparative study of the influence of malignant tumor on host metabolism in mice and man: evaluation of an experimental model. Cancer, 1978. 42(2): p. 453-61.

183. Ruud, J., et al., Deletion of the gene encoding MyD88 protects from anorexia in a mouse tumor model. Brain, behavior, and immunity, 2010. 24(4): p. 554-557.

184. Wang, W., et al., Prostaglandin E and prostacyclin receptor expression in tumor and host tissues from MCG 101-bearing mice: a model with prostanoid-related cachexia. Int J Cancer, 2005. 115(4): p. 582-90.

185. Lundholm, K., et al., Relationship of food intake, body composition, and tumor growth to host metabolism in nongrowing mice with sarcoma. Cancer Res, 1980. 40(7): p. 2516-22.

186. Gelin, J., C. Andersson, and K. Lundholm, Effects of indomethacin, cytokines, and cyclosporin A on tumor growth and the subsequent development of cancer cachexia. Cancer Res, 1991. 51(3): p. 880-5.

187. Cahlin, C., et al., Experimental cancer cachexia: the role of host-derived cytokines interleukin (IL)-6, IL-12, interferon-gamma, and tumor necrosis factor alpha evaluated in gene knockout, tumor-bearing mice on C57 Bl background and eicosanoid-dependent cachexia. Cancer Res, 2000. 60(19): p. 5488-93.

188. Mormede, C., et al., Conditioned taste aversion with lipopolysaccharide and peptidoglycan does not activate cytokine gene expression in the spleen and hypothalamus of mice. Brain Behav Immun, 2004. 18(2): p. 186-200.

189. Sandstrom, R., J. Gelin, and K. Lundholm, The effect of indomethacin on food and water intake, motor activity and survival in tumour-bearing rats. Eur J Cancer, 1990. 26(7): p. 811-4. 


\section{LIST OF REFERENCES}

190. West, D.B., et al., Lithium chloride, cholecystokinin and meal patterns: evidence that cholecystokinin suppresses meal size in rats without causing malaise. Appetite, 1987. 8(3): p. 221-7.

191. Lal, J., Possible role of prostaglandins in the regulation of food intake in the newborn rat. Arch Int Pharmacodyn Ther, 1984. 272(1): p. 140-9.

192. Doggett, N.S. and K. Jawaharlal, Some observations on the anorectic activity of prostaglandin F2alpha. Br J Pharmacol, 1977. 60(3): p. 409-15.

193. Horsley, V. and G.K. Pavlath, Prostaglandin F2(alpha) stimulates growth of skeletal muscle cells via an NFATC2-dependent pathway. J Cell Biol, 2003. 161(1): p. 111-8.

194. Elander, L., et al., Cyclooxygenase-1 mediates the immediate corticosterone response to peripheral immune challenge induced by lipopolysaccharide. Neurosci Lett, 2010. 470(1): p. 10-2.

195. Garcia-Bueno, B., J. Serrats, and P.E. Sawchenko, Cerebrovascular cyclooxygenase-1 expression, regulation, and role in hypothalamic-pituitary-adrenal axis activation by inflammatory stimuli. J Neurosci, 2009. 29(41): p. 12970-81.

196. Wisse, B.E., et al., Evidence that lipopolysaccharide-induced anorexia depends upon central, rather than peripheral, inflammatory signals. Endocrinology, 2007. 148(11): p. 5230-7.

197. Nakano, Y., et al., Astrocytic TLR4 expression and LPS-induced nuclear translocation of STAT3 in the sensory circumventricular organs of adult mouse brain. J Neuroimmunol, 2015. 278: p. 144-58.

198. Laflamme, N. and S. Rivest, Toll-like receptor 4: the missing link of the cerebral innate immune response triggered by circulating gram-negative bacterial cell wall components. Faseb j, 2001. 15(1): p. 155-163.

199. Schaffler, A., J. Scholmerich, and B. Salzberger, Adipose tissue as an immunological organ: Toll-like receptors, Clq/TNFs and CTRPs. Trends Immunol, 2007. 28(9): p. 3939.

200. Meek, I.L., M.A. Van de Laar, and E.V. H, Non-Steroidal Anti-Inflammatory Drugs: An Overview of Cardiovascular Risks. Pharmaceuticals (Basel), 2010. 3(7): p. 2146-2162. 



\section{Papers}

The articles associated with this thesis have been removed for copyright reasons. For more details about these see:

http://urn.kb.se/resolve?urn=urn:nbn:se:liu:diva- 132640 